\title{
What drives the spatial variability of primary productivity and matter fluxes in the north-west African upwelling system? A modelling approach
}

\author{
Pierre-Amaël Auger ${ }^{1,2,5}$, Thomas Gorgues ${ }^{1}$, Eric Machu ${ }^{1,3}$, Olivier Aumont ${ }^{1, \mathrm{a}}$, and Patrice Brehmer B $^{2,4}$ \\ ${ }^{1}$ Univ. Brest, CNRS, IRD, Ifremer, Laboratoire d'Océanographie Physique et Spatiale (LOPS), \\ IUEM, 29280, Plouzané, France \\ ${ }^{2}$ Institut de Recherche pour le Développement (IRD), Laboratoire de l'Environnement MARin (LEMAR), UMR 195 \\ CNRS/IRD/UBO/Ifremer, Campus UCAD-IRD, BP 1386, Dakar, Senegal \\ ${ }^{3}$ ESP/CAD, Laboratoire de Physique de 1'Atmosphère et de l'Océan Siméon Fongang (LPAO-SF), BP 5085, \\ Dakar-Fann, Senegal \\ ${ }^{4}$ Institut Sénégalais de Recherche Agricole (ISRA)/Centre de Recherche Océanographique de Dakar-Thiaroye (CRODT), \\ Pole de recherche de Hann (PRH), BP 2241, Dakar, Senegal \\ ${ }^{5}$ Instituto Milenio de Oceanografia and Escuela de Ciencias del Mar, Pontificia Universidad Catolica de Valparaiso, \\ Valparaiso, Chile \\ a now at: Laboratoire d'Océanographie et de Climatologie: Expérimentation et Analyse Numérique (LOCEAN), Institut \\ Pierre-Simon Laplace (IPSL), UPMC/CNRS/IRD/MNHN, 4 Place Jussieu, Case 100, 75252 Paris Cedex 05, France
}

Correspondence to: Pierre-Amaël Auger (pierreamael.auger@gmail.com)

Received: 24 April 2016 - Published in Biogeosciences Discuss.: 4 May 2016

Revised: 19 October 2016 - Accepted: 2 November 2016 - Published: 30 November 2016

\begin{abstract}
A comparative box analysis based on a multi-decadal physical-biogeochemical hindcast simulation (1980-2009) was conducted to characterize the drivers of the spatial distribution of phytoplankton biomass and production in the north-west (NW) African upwelling system. Alongshore geostrophic flow related to large-scale circulation patterns associated with the influence of coastal topography is suggested to modulate the coastal divergence, and then the response of nutrient upwelling to wind forcing. In our simulation, this translates into a coastal upwelling of nitrate being significant in all regions but the Cape Blanc (CB) area. However, upwelling is found to be the dominant supplier of nitrate only in the northern Saharan Bank (NSB) and the Senegalo-Mauritanian (SM) regions. Elsewhere, nitrate supply is dominated by meridional advection, especially off Cape Blanc. Phytoplankton displays a similar behaviour with a supply by lateral advection which equals the net coastal phytoplankton growth in all coastal regions except the Senegalo-Mauritanian area. Noticeably, in the Cape Blanc area, the net coastal phytoplankton growth is mostly
\end{abstract}

sustained by high levels of regenerated production exceeding new production by more than twofold, which is in agreement with the locally weak input of nitrate by coastal upwelling. Further offshore, the distribution of nutrients and phytoplankton is explained by the coastal circulation. Indeed, in the northern part of our domain (i.e. Saharan Bank), the coastal circulation is mainly alongshore, resulting in low offshore lateral advection of nutrients and phytoplankton. Conversely, lateral advection transports coastal nutrients and phytoplankton towards offshore areas in the latitudinal band off the Senegalo-Mauritanian region. Moreover, this latter offshore region benefits from transient southern intrusions of nutrient-rich waters from the Guinean upwelling.

\section{Introduction}

Among the four major eastern boundary upwelling systems (EBUS), the north-west (NW) African upwelling region is the most spatially and seasonally variable in terms of primary 
productivity (Carr and Kearns, 2003). This variability may impact the distribution and abundance of fish populations, and their associated fisheries, on a large range of timescales (Arístegui et al., 2009). It also constrains the dynamics of nutrient and organic carbon exports from the coastal margin (Helmke et al., 2005; Muller-Karger et al., 2005). Various studies have established that upwelling-driven nutrient supply is the key factor regulating chlorophyll concentration and primary production off NW Africa (Lathuilière et al., 2008; Messié and Chavez, 2014; Ohde and Siegel, 2010; Pradhan et al., 2006). However, the mechanisms that control the spatiotemporal variability of primary productivity are still poorly understood.

In EBUS, primary production and phytoplankton biomass are first enhanced by the wind-driven coastal upwelling of nutrient-rich waters into the euphotic zone (Allen, 1973). Upwelled waters are redistributed by advection processes, while turbulent mixing accounts for their dilution into surrounding waters. Mixing naturally acts against the build-up of plankton biomass. Indeed, the nutrient utilization can only be optimized by retentive physical mechanisms in the coastal area, which enhance microbial remineralization of particulate organic matter and zooplankton excretion, and then regenerated production through ammonium consumption.

During the last decade, several studies focused on the characterization of the variability of satellite-derived surface chlorophyll in the NW African region which they interpreted with regard to environmental forcing (Lathuilière et al., 2008; Pradhan et al., 2006; Thomas et al., 2001). One of their main findings was that the seasonal variability of wind forcing is the main driver of the surface chlorophyll seasonal variability. If this main result is expected, it does not give the full account of the latitudinal discrepancies of the seasonal variability of the surface chlorophyll, and the related underlying processes within the NW African upwelling system. Indeed, the region between 24 and $33^{\circ} \mathrm{N}$ (most of the Moroccan subregion including the northern Saharan Bank) is characterized by a weak seasonality and chlorophyll confined to the coast. The Cape Blanc area (19-24 $\mathrm{N}$, including the southern Saharan Bank) also presents a weak seasonality but is the site of a persistent offshore extension of the coastal chlorophyll pattern. In the Senegalo-Mauritanian region $\left(10-19^{\circ} \mathrm{N}\right)$, chlorophyll is enhanced together with a large offshore extension during winter and spring, followed by an abrupt drop during summer. Lathuilière et al. (2008) suggest that nutrient limitation is the key factor that explains the weak offshore extension of chlorophyll in the north. In the south, they partly attribute the drop of chlorophyll to the seasonal intrusion of nutrient-depleted waters from the North Equatorial Counter Current (NECC).

Here, we propose a modelling approach to gain the first mechanistic understanding of the underlying processes controlling the spatial variability of primary productivity, and to test the satellite-based hypothesis proposed by Lathuilière et al. (2008). In our study, outputs of a multi-decadal physical-biogeochemical hindcast simulation (1980-2009; see Auger et al., 2015) were used to spatially characterize the drivers of phytoplankton biomass and production in the NW African upwelling system with a particular focus on the mechanisms that control the sensitivity of primary productivity to the wind forcing and the coastal upwelling. To this end, a comparative box analysis representing homogeneous subregions in the NW African upwelling system has been conducted. The sub-regions have been defined using the nearsurface horizontal circulation patterns. In each box, we analysed the dynamics of primary productivity and nutrients with regard to advective and diffusive matter fluxes at the boundaries and local biological production and/or uptake. The nature and variability of the matter exported from the coastal margin to the adjacent open ocean were also subsequently depicted.

First, we present the model configuration and a validation of near-surface circulation and surface chlorophyll biomass using in situ and satellite data (Sects. 2.1 and 2.2, respectively). Then, we describe the meridional variability of wind forcing, ocean response and primary productivity as simulated by the model in the different coastal (Sect. 3.1) and offshore boxes (Sect. 3.2), on annual average and also during spring (seasonal maximum of the chlorophyll offshore extension as shown in Lathuilière et al, 2008). Each section is split in three parts which describe the meridional variability of (i) the wind forcing, current velocity and nitrate fluxes, (ii) the primary production (PP), phytoplankton biomass and phytoplankton fluxes, and (iii) the sources and sinks of nitrate concentration and phytoplankton biomass in each box. Finally, we discuss in Sect. 4 (i) the sensitivity of coastal upwelling to the wind forcing along the NW African coast, (ii) the meridional variability of coastal phytoplankton biomass and PP (new and regenerated production) in relation to matter transfers and (iii) the meridional variability of the offshore extension of coastal chlorophyll off NW Africa.

\section{Materials and methods}

\subsection{Physical-biogeochemical model}

A multi-decadal hindcast simulation of the physicalbiogeochemical dynamics in the NW African upwelling system was run over the period 1980-2009. We used the threedimensional (3-D) primitive equations, sigma-coordinates, free surface regional oceanic modeling system (ROMS Shchepetkin and McWilliams, 2005) configured for the NW African upwelling system (Machu et al., 2009; Marchesiello and Estrade, 2009). Model parameterizations, including a parameterization of the Mediterranean outflow, are described by Marchesiello and Estrade (2009). The physical model was coupled to a biogeochemical model (PISCES - Aumont et al., 2003; Aumont and Bopp, 2006) which simulates plankton productivity and carbon biomass based upon the 
main nutrients (nitrate, ammonium, phosphate, silicate and iron). This model includes two size classes of phytoplankton (nanoflagellates and diatoms), zooplankton (ciliates and copepods) and two classes of detritus (the latter differ by their sinking velocity: 5 and $30 \mathrm{~m} \mathrm{~d}^{-1}$ for small and large particulate material, respectively). Phytoplankton growth depends on light, temperature and the external availability in nutrients. Diatoms differ from nanoflagellates by their silicate requirement, higher requirement in iron (Sunda and Huntsman, 1997) and higher half-saturation constant due to larger size. Microzooplankton differs from mesozooplankton by food diet (related to the prey / predator size ratio), grazing rates and mortality parameterization. PISCES has previously been used in global (e.g. Aumont et al., 2003; Aumont and Bopp, 2006; Gorgues et al., 2010), basin-scale (e.g. Gorgues et al., 2005; José et al., 2014) and regional upwelling studies (e.g. Albert et al., 2010; Auger et al., 2015; Echevin et al., 2008).

Heat, solar and water fluxes from the CFSR atmospheric reanalysis $\left(1 / 3^{\circ}\right.$ resolution, NCEP Climate Forecast System Reanalysis, Saha et al., 2010) were used to force our interannual simulation at a $6 \mathrm{~h}$ timescale. Lateral open boundary conditions of both physical and biogeochemical fields were provided by a 5-day archived NEMO-PISCES simulation of the North Atlantic basin $\left(1 / 4^{\circ}\right.$ resolution, T. Gorgues, personal communication, 2013). Surface nutrient fertilization were solely provided by iron dust deposition, parameterized using a modelled climatology of the atmospheric dust deposition (for details, see Aumont et al., 2008).

The topography was based on GEBCO $1^{\prime}$ resolution (General Bathymetric Chart of the Oceans, http://www.gebco. net). A "child" grid focused on the NW African upwelling $\left(10-35^{\circ} \mathrm{N} / 9-23^{\circ} \mathrm{W}, 1 / 12^{\circ}\right.$ resolution, eddy-resolving) was embedded in a lower-resolution "parent" grid $\left(5-40^{\circ} \mathrm{N} / 5\right.$ $30^{\circ} \mathrm{W}, 1 / 4^{\circ}$ resolution) through a two-way coupling (AGRIF - Debreu et al., 2012). The use of this technique limits the influence of discontinuities emerging from low spatio-temporal resolution of open boundary conditions on the "child" solution, and also produces upscaling effects on the "parent" solution. More details on the simulation can be found in Auger et al. (2015).

\subsection{Model validation}

As previously described by Auger et al. (2015), the general distribution of sea surface temperature (SST) agrees well with satellite data from the Advanced Very High Resolution Radiometer (AVHRR) although a warm (cold) bias of about $1{ }^{\circ} \mathrm{C}$ exists in offshore (nearshore) SST. The coastal region of cold surface waters is notably narrower in the model, particularly off Cape Blanc and, during the upwelling winter season, off Mauritania (see Fig. 2 in Auger et al., 2015). However, the general circulation and its seasonal variability are well reproduced by the model (Fig. 1, winter and summer averages), as attested by climatology of near-surface currents from the model $(15 \mathrm{~m})$ and derived from satellite-tracked near-surface drifting buoy (1979-present, $1 / 2^{\circ}$ resolution; Lumpkin and Johnson, 2013).

As part of the eastern branch of the North Atlantic subtropical gyre, the Canary Current flows equatorward along the NW African coast and separates from the coast around Cape Blanc $\left(19-21^{\circ} \mathrm{N}\right)$ where it feeds the North Equatorial Current (Fig. 1e). South of $19^{\circ} \mathrm{N}$, a large cyclonic recirculation is found between the south-westward flowing Canary Current and the coast, especially in summer when trade winds extend farther north (see Barton et al., 1998; Mittelstaedt, 1983, 1991). It generates a poleward alongshore flow at its eastern flank, generally referred to as the Mauritanian Current (Aristegui et al., 2009). The southern branch of the recirculation gyre is fed by the eastward-flowing North Equatorial Counter Current (NECC) which is located near $10^{\circ} \mathrm{N}$ in summer and $5^{\circ} \mathrm{N}$ in winter (Mittelstaedt, 1991; Stramma et al., 2005). A particularly intense coastal upwelling jet flowing equatorward (Canary Upwelling Current) is present all year round north of Cape Blanc due to strong and constant upwelling-favourable winds (Benazzouz et al., 2014). The upwelling filaments off Cape Ghir and Cape Bojador are related to strong seaward deflections of the coastal current. As a matter of fact, strong westward velocities off Cape Bojador most likely limits the drifter sampling over the Saharan Bank (Fig. 1). Surface currents then turn west in the intergyre region off Cape Blanc feeding the North Equatorial Current (Fig. 1e). In the Senegalo-Mauritanian region, surface currents are directed south-westward during the winter upwelling season. Alternatively, a moderate expression of the poleward Mauritanian Current lays south of Cape Blanc both in the model and in the data during summer when upwellingfavourable winds are weak. However, this poleward current does not persist during winter in our simulation as well as in the drifter climatology offshore of Mauritania. The seasonality of the coastal current in the same latitudinal band, a crucial feature, is nevertheless well simulated with strong equatorward advection in winter and moderate poleward advection in summer. Noticeably, the flow of the undercurrent over the slope is always poleward (not shown) in agreement with observations (Mittelstaedt, 1983).

Besides this, the model represents, at latitudes around Cape Blanc, the sharp gradient of nutrient concentrations in upwelling source waters between nutrient-poor North Atlantic Central Water (NACW) and nutrient-rich South Atlantic Central Water (SACW), respectively north and south of Cape Blanc, observed from the World Ocean Atlas 2013 (Garcia et al., 2014; see the contours of nitrate concentration at $100 \mathrm{~m}$ depth in Fig. 1). This actually results from the deepening of the poleward undercurrent transporting SACW, and its intensive mixing with NACW north of Cape Blanc (Mittelstaedt, 1983). The seasonal variability is reproduced except for a negative bias in nitrate concentration off Cape Blanc in summer. This bias between model and observations may be due to an overestimation of the southward NACW 


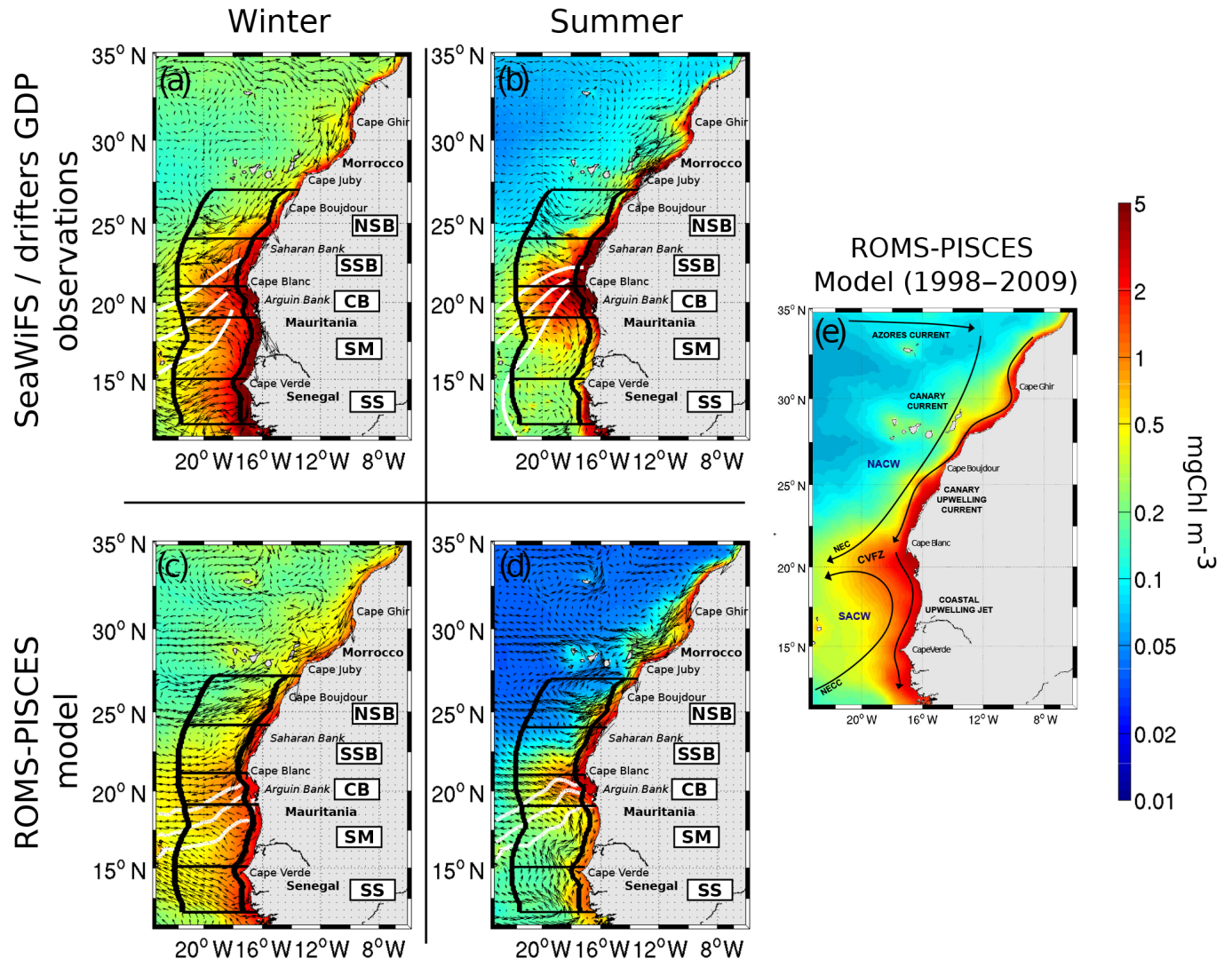

Figure 1. Seasonal climatology of sea surface chlorophyll concentrations (background) from SeaWiFS satellite data (1998-2009), nearsurface currents (vectors) from the Global Drifter Program (GDP, 1979-present, Lumpkin and Johnson, 2013) and nitrate concentration at $100 \mathrm{~m}$ depth (white contours of 10,15 and $20 \mathrm{mmol} \mathrm{N} \mathrm{m}^{-3}$ from north to south) from the World Ocean Atlas 2013 (Garcia et al., 2014 ) in (a) winter (January-March) and (b) summer (July-September). Same seasonal climatology computed with the 5-day outputs of ROMSPISCES in (c) winter and (d) summer. Main surface currents and deep water masses over the study area are presented over a map of simulated surface chlorophyll averaged over the SeaWIFS period (e). NEC: North Equatorial Current; NECC: North Equatorial Counter current; CVFZ: Cape Verde Frontal Zone; NACW: North Atlantic Central Water; SACW: South Atlantic Central Water. The 5 coastal and 5 offshore boxes used in this study are superimposed (black boxes): northern Saharan Bank (NSB), southern Saharan Bank (SSB), Cape Blanc area (CB), Senegalo-Mauritanian region (SM) and southern Senegal region (SS).

transport by the Canary Current in the model (Fig. 1) and/or a deepening of the SACW flowing northward that occurs too early. Yet, in situ observations off NW Africa are scarce and NACW has already been encountered south of the Cape Verde Frontal Zone as far as Senegal (Verstraete, 1985).

The spatial and seasonal variability of surface chlorophyll is consistent with SeaWiFS satellite data (Fig. 1). In both model and satellite data, chlorophyll concentrations are globally maximum in the coastal upwelling (5$10 \mathrm{mg} \mathrm{Chl} \mathrm{m}^{-3}$ ) and decrease offshore toward the subtropical gyre $\left(0.1-0.2 \mathrm{mg} \mathrm{Chl} \mathrm{m}^{-3}\right)$. However, nearshore chlorophyll concentrations and values of PP (see Auger et al., 2015) are lower than satellite-based estimates (Carr, 2001; Gregg et al., 2003). Thus, the cross-shore gradient is not as sharp in the model as in satellite observations. However, SeaWiFS may actually overestimate in situ data in the Mauritanian upwelling. Gregg and Casey (2004) attributed this over- estimation to unmasked Saharan dust in the atmospheric correction algorithm (Moulin et al., 2001). Increased overestimation with increasing chlorophyll concentrations were also evidenced (Gregg and Casey, 2004). Moreover, model results fall in the range of in situ measurements in the Mauritanian upwelling (Atlantic Meridional Transect, AMT; Aiken et al., 2009; Gibb et al., 2000; Marañon et al., 2000; Pradhan et al., 2006) which reveal lower chlorophyll concentrations than SeaWiFS data. Large phytoplankton cells (diatoms) are generally dominant in the coastal upwelling region (not shown) in agreement with AMT measurements (Aiken et al., 2009). It shows an increasing contribution of smaller cells toward the open ocean. Our model is also able to reproduce this observed shift in phytoplankton community structure from nearshore to offshore (Gutiérrez-Rodríguez et al., 2011).

The seasonal variability, both in the model and in the data (Fig. 1), is maximum in the Senegalo-Mauritanian region, 


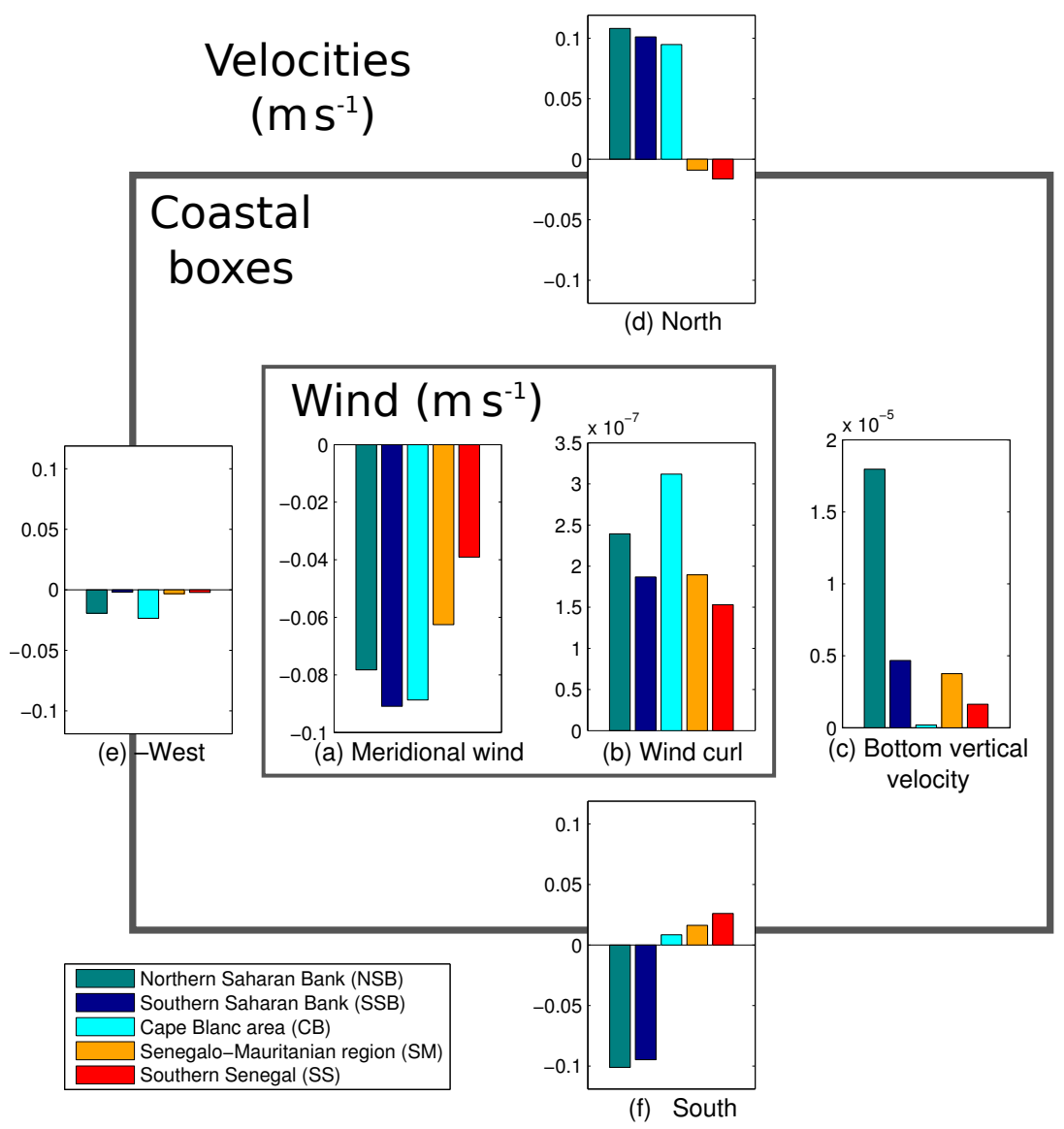

Figure 2. Annual mean of (a) wind intensity $\left(\mathrm{m} \mathrm{s}^{-1}\right)$ and (b) wind curl $\left(\mathrm{s}^{-1}\right)$ at the surface of the coastal boxes, (c) upwelling intensity (bottom vertical velocity, in $\mathrm{m} \mathrm{s}^{-1}$ ) within the coastal boxes and lateral velocities at the (d) northern, (e) western and (f) southern boundaries $\left(\mathrm{m} \mathrm{s}^{-1}\right)$. Vertical and lateral velocities are defined as positive inward and upward. Each colour corresponds to a box (see legend).

and minimum off Cape Blanc. Over the Saharan Bank, peaks of plankton productivity occur in spring and summer whereas a relaxation of trade winds globally induces a lower production in fall. In contrast, plankton productivity peaks in winter and spring in the Senegalo-Mauritanian region. As described from satellite observations (Lathuilière et al., 2008), the surface chlorophyll maximum is confined to the coast north of Cape Bojador. The offshore extension of chlorophyll then increases equatorward from the Saharan Bank to Cape Blanc in summer, and to the Senegalo-Mauritanian region in winter. Noticeably, maximum offshore extension is found yearround off Cape Blanc $\left(21^{\circ} \mathrm{N}\right)$. South of Cape Blanc, maximum offshore extension occurs when nearshore chlorophyll concentrations are maximum in winter and spring, whereas the contrary is found north of Cape Blanc.

\subsection{Box analysis}

In order to identify the factors controlling the meridional variability of primary productivity off the NW African coast between 12 and $27^{\circ} \mathrm{N}$, we carried out a box analysis focusing on nitrate (the main limiting nutrient) and phytoplankton carbon budgets based on a climatology of model outputs over our simulation period (1980-2009). First, we distinguished between the coastal region (from the coast to $0.5^{\circ}$ offshore) and the offshore region (covering $4^{\circ}$ of longitude further offshore). Second, based on near-surface horizontal circulation patterns in the coastal region, offshore export and bathymetric considerations, the study domain was split into five latitudinal bands (see Fig. 1). The vertical extension of the five coastal and five offshore boxes was chosen from the free surface down to $100 \mathrm{~m}$ (or the bottom in areas shallower than $100 \mathrm{~m}$ ) to encompass the euphotic layer.

Starting from the northern part of our simulated domain, the circulation off the Saharan Bank $\left(21-27^{\circ} \mathrm{N}\right)$ is generally characterized by year-round equatorward velocities. Moreover, strong offshore velocities differentiate the northern $\mathrm{Sa}$ haran Bank (NSB, 24-27 $\mathrm{N}$ ) from the southern Saharan Bank (SSB, 21-24 $\mathrm{N}$ ).

In the southernmost part of our domain, the SenegaloMauritanian region $\left(12-19^{\circ} \mathrm{N}\right)$ is characterized by a seasonal reversal of meridional velocities with southward (northward) direction in winter (summer) and by enhanced westward 
velocities in winter. Noticeably, we separated the southern Senegal region (SS, $12-15^{\circ} \mathrm{N}$ ) from the rest of the SenegaloMauritanian region $\left(\mathrm{SM}, 15-19^{\circ} \mathrm{N}\right)$ because the circulation patterns differ significantly and the continental shelf is wider south of Cape Verde, implying different coastal dynamics.

At the frontier of the two previous main zones, the Cape Blanc area $\left(\mathrm{CB}, 19-21^{\circ} \mathrm{N}\right)$, including the Arguin Bank, is the place of a meridional convergence of surface water masses and strong offshore velocities.

In these boxes, meridional wind speed and wind curl were averaged to respectively compare upwelling-favourable forcings and Ekman pumping between boxes. Similarly, the horizontal and vertical velocities and advective and diffusive fluxes of nitrate and phytoplankton biomass $\left(\mathrm{mol} \mathrm{m}^{-2} \mathrm{~s}^{-1}\right)$ were averaged over each edge of each box, and the phytoplankton biomass and PP (new and regenerated) were averaged and compared between boxes. Net biological rates (biological source minus sink) in each box were also computed to offer an integrated view of the source and sink terms of phytoplankton biomass and nitrate in each box $\left(\mathrm{mol} \mathrm{s}^{-1}\right)$ (i.e. the respective contribution of the advective and/or diffusive transport at the box boundaries and the net biological rate). Additionally, the mean residence time of upwelled water masses in each box was derived from a lagrangian tracking of passive particles based on 3-D current fields from the physical model (see full description in Auger et al., 2015). The meridional variability of the ecosystem functioning could then be fully characterized.

\section{Results}

\subsection{Meridional variability in the coastal region}

\subsubsection{Wind forcing, current velocity and nitrate fluxes}

Mean annual coastal wind forcing imposed in our simulation, i.e. meridional wind intensity (negative equatorward) and wind curl, are presented in Fig. 2a, b. Equatorward upwelling-favourable wind is maximum in the southern Saharan Bank and off Cape Blanc (Fig. 2a). Wind curl is positive everywhere, implying upward Ekman pumping, and shows weak meridional variability except for a clear maximum off Cape Blanc (Fig. 2b).

Mean annual current velocities (vertical and horizontal) averaged over each edge of the coastal boxes (defined as positive inward and upward) are presented in Fig. 2c-f. Coastal upwelling shows a strong latitudinal variability with a clear weakening southward (Fig. 2c). Maximum upwelling intensity is mostly found over the northern Saharan Bank which is under the influence of particularly active upwelling cells found in Cape Bojador and Cape Juby areas (Arístegui et al., 2004; Barton et al., 2004). Minimum upwelling intensity is found off Cape Blanc. Observational data are known to be scarce in our study region. However vertical velocities fall in the range of the few studies that have been published with observed (Benítez-Barrios et al., 2011) or modelled values (Mason et al., 2012) focusing on northern Morocco.

Cross-shore velocities are everywhere directed offshore with maxima off the northern Saharan Bank and Cape Blanc (Fig. 2e) where advection by filaments is the most active (Barton et al., 2004; García-Muñoz et al., 2005; Karakaş et al., 2006).

Southward circulation is found over the Saharan Bank as the signature of a strong upwelling-induced coastal jet (Fig. 2d-e). On the contrary, the northward circulation found in the Senegalo-Mauritanian region represents the eastern branch of the large-scale cyclonic circulation characterizing the region of the recirculation gyre (Mittelstaedt, 1991). The Cape Blanc area is thus characterized by the average meridional convergence of water masses from the Saharan Bank and Mauritania, and this occurs together with minimum coastal upwelling intensity (Fig. 2c).

Mean annual nitrate fluxes (vertical and horizontal) averaged over each edge of the coastal boxes are presented in Fig. 3a-d. Vertical (upwelling-induced) nitrate supply is maximum in the northern Saharan Bank and the SenegaloMauritanian region (Fig. 3a), and minimum off Cape Blanc according to minimum upwelling intensity (see above). However, the southward weakening of upwelling intensity is not reflected in upwelling-induced nitrate supply. Indeed, the vertical nitrate supply is higher south of Cape Blanc than in the southern Saharan Bank, contrasting with upwellingfavourable wind intensity, owing to higher nitrate concentration in upwelling source waters south of Cape Blanc (Fig. 1). Offshore fluxes of nitrate are found to be maximum in the Cape Blanc and Senegalo-Mauritanian regions. Noticeably, they are significantly higher off Cape Blanc than in the northern Saharan Bank despite equivalent cross-shore velocities (Fig. 3c).

\subsubsection{Primary production, phytoplankton biomass and phytoplankton fluxes}

The meridional coastal distribution of the annual primary production shows a well-marked maximum off Cape Blanc (Fig. 4a), while similar levels of PP are simulated in the boxes north and south of Cape Blanc, respectively.

The annual mean new production follows the upwellinginduced nitrate supply (Figs. 3a and 4a), except off Cape Blanc where maximum new production is associated with minimum vertical nitrate supply. On the contrary, regenerated production (ammonium consumption, Fig. 4a) shows a meridional structure opposed to the one seen in upwellinginduced nitrate supplies (Fig. 3a) with higher levels in the southern Saharan Bank, off Cape Blanc (although showing the minimum $f$ ratio; Fig. 4b), as well as in the southern Senegal coastal box (Fig. 4a). This agrees with the meridional variability of the ammonium production by microbial remineralization (Fig. 5a), which brings $60-70 \%$ of the am- 

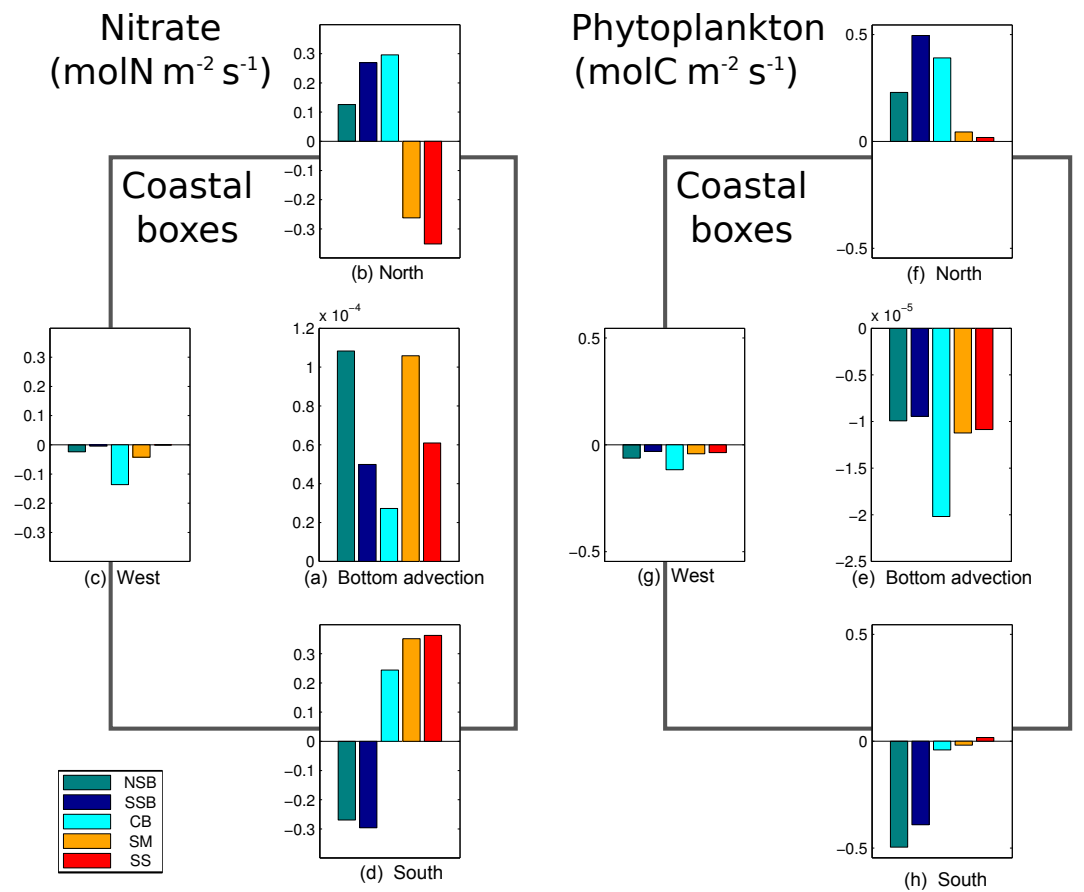

Figure 3. Annual mean of (a) vertical nitrate fluxes at the bottom of the coastal boxes and (b-d) lateral fluxes at the (b) northern, (c) western and (d) southern boundaries $\left(\mathrm{mol} \mathrm{N} \mathrm{m}^{-2} \mathrm{~s}^{-1}\right)$; annual mean of (e) vertical phytoplankton fluxes at the bottom of the coastal boxes and $(\mathbf{f}-\mathbf{h})$ lateral fluxes at the (f) northern, (g) western and (h) southern boundaries $\left(\mathrm{mol} \mathrm{C} \mathrm{m} \mathrm{s}^{-2} \mathrm{~s}^{-1}\right)$. Vertical and lateral fluxes are defined as positive inward and upward. Note that the fluxes due to vertical diffusion are 1 order of magnitude lower compared to advection in the coastal boxes. Each colour corresponds to a box (see legend): northern Saharan Bank (NSB), southern Saharan Bank (SSB), Cape Blanc area (CB), Senegalo-Mauritanian region (SM) and southern Senegal region (SS).

monium (not shown). Microbial remineralization depends on detritus concentration, and then potentially on lateral inputs of organic matter. Zooplankton excretion is also minimum in the northern Saharan Bank with a significant overall contribution of mesozooplankton (20-30\%, not shown) and to a lesser extent microzooplankton (5-15\%, not shown). Noticeably, in all coastal boxes except the northern Saharan Bank, $\mathrm{PP}$ is mostly related to regenerated production (Fig. $4 \mathrm{~b} ; f$ ratio $<0.5$ ).

Phytoplankton biomass, averaged over the $100 \mathrm{~m}$ depth of the boxes, mirrors that of PP with a maximum off Cape Blanc (Fig. 4c). However, phytoplankton exhibits higher biomass north of Cape Blanc than south, which does not translate into higher PP in the northern boxes (i.e. north Saharan Bank and south Saharan Bank). Phytoplankton biomass in the Senegalo-Mauritanian region and the north Saharan Bank are similar while PP is different. It is noteworthy that maximum phytoplankton biomass is found off Cape Blanc and the southern Saharan Bank despite the fact that upwellinginduced nitrate supplies are at a minimum at those locations (Fig. 3a).

The vertical export of phytoplankton biomass is maximum off Cape Blanc (Fig. 3e). Otherwise, there is weak meridional variation of vertical phytoplankton export. The meridional variability of horizontal phytoplankton fluxes (Fig. $3 \mathrm{f}-\mathrm{h}$ ) is nearly the same as current velocities (Fig. 2d-f), which contrasts with nitrate. Maximum fluxes of phytoplankton are directed southward and occur in coastal boxes north of Cape Blanc. In particular, the southern Saharan Bank and Cape Blanc boxes are characterized by strong horizontal inputs of phytoplankton through their northern boundaries. In the Senegalo-Mauritanian region, the southward fluxes of phytoplankton biomass are interestingly opposed to the northward flux of nitrate. Zonal fluxes of phytoplankton are directed offshore with a maximum off Cape Blanc and in the northern Saharan Bank and show maxima off Cape Blanc and in the northern Saharan Bank (Fig. 3g). This latter feature contrasts with nitrate fluxes (Fig. 3c).

\subsubsection{Meridional distribution of the processes controlling the coastal nitrate concentration and phytoplankton biomass}

The annual mean contribution of each source and sink term (i.e. advective and/or diffusive tracer fluxes and net biological rate) to the total rate of change of nitrate concentration and phytoplankton biomass in each coastal box are presented in Fig. 6a, b. From northern to southern boxes, the functioning in each box is described. Note that the contribution of dif- 

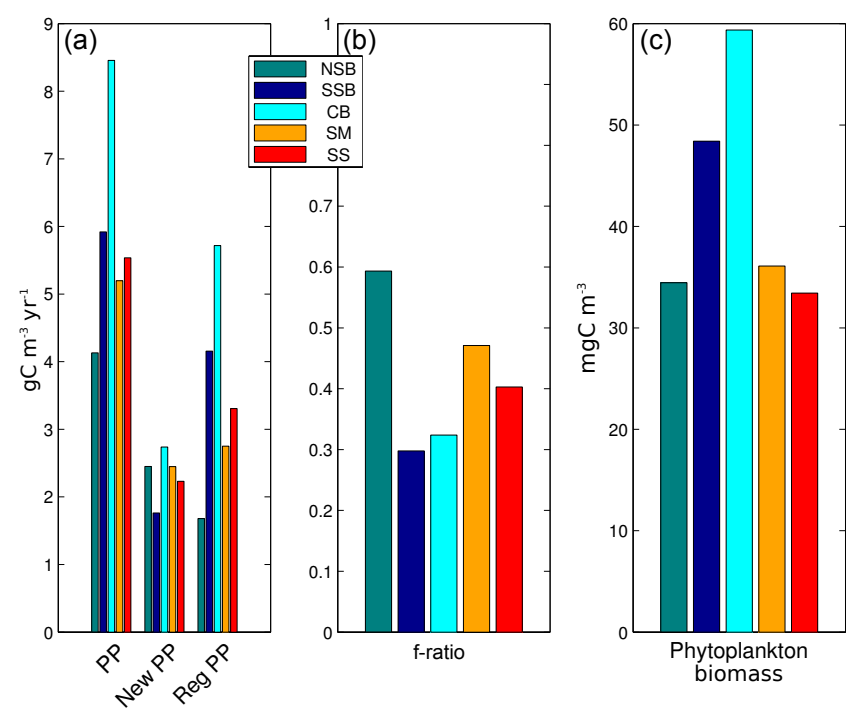

Figure 4. Annual mean of (a) primary production (PP, $\left.\mathrm{g} \mathrm{C} \mathrm{m}^{-3} \mathrm{yr}^{-1}\right)$, new production $\left(\mathrm{g} \mathrm{C} \mathrm{m}^{-3} \mathrm{yr}^{-1}\right)$ and regenerated production $\left(\mathrm{g} \mathrm{C} \mathrm{m}^{-3} \mathrm{yr}^{-1}\right.$ ), (b) $f$ ratio (new and/or regenerated production) and (c) phytoplankton biomass $\left(\mathrm{mg} \mathrm{Cm}^{-3}\right)$ in the coastal boxes. Each colour corresponds to a box (see legend): northern Saharan Bank (NSB), southern Saharan Bank (SSB), Cape Blanc area (CB), Senegalo-Mauritanian region (SM) and southern Senegal region (SS).

fusion, i.e. horizontal and vertical mixing, is negligible compared to advection.

In the northern Saharan Bank, the nitrate supply seems to be dominated by coastal upwelling, which exceeds nitrate advection from the north. The major sink is found to be horizontal advection, shared between southward and westward (offshore) advection, actually exceeding biological uptake. The net phytoplankton growth exceeds the transport of phytoplankton by advection through the northern boundary of the northern Saharan Bank box. Phytoplankton is then equally exported offshore and southward, and to a much lesser extent through sedimentation below $100 \mathrm{~m}$.

In the southern Saharan Bank, the nitrate supply is shared between advection through the northern boundary from the northern Saharan Bank and coastal upwelling. Southward advection to the Cape Blanc area is then the main nitrate sink while both contributions from the biological sink and offshore export are reduced compared to their role in the northern Saharan Bank. In the southern Saharan Bank, the net local phytoplankton growth is no longer the main source of phytoplankton since the transport of phytoplankton from the northern Saharan Bank is more important. Phytoplankton biomass is then exported southward and offshore, the vertical export below $100 \mathrm{~m}$ depth still being low.

Off Cape Blanc, as in the southern Saharan Bank, the nitrate budget is mostly driven by horizontal advective fluxes. The nitrate supply is mostly due to transport through the southern and northern boundaries from the Senegalo-
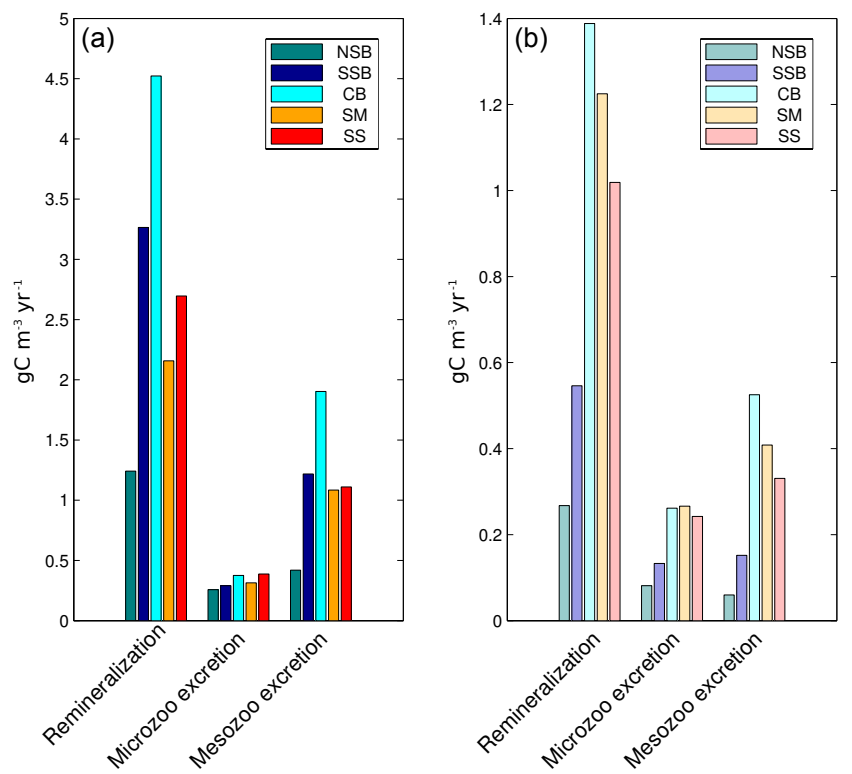

Figure 5. Remineralization rate of organic carbon $\left(\mathrm{g} \mathrm{C} \mathrm{m}^{-3} \mathrm{yr}^{-1}\right)$ through microbial activity and zooplankton excretion (micro- and mesozooplankton) (a) averaged annually in the coastal boxes and (b) over the spring period (March-May) in the offshore boxes. Each colour corresponds to a box (see legend): northern Saharan Bank (NSB), southern Saharan Bank (SSB), Cape Blanc area (CB), Senegalo-Mauritanian region (SM) and southern Senegal region (SS).

Mauritanian region and the southern Saharan Bank, respectively. Most of the nitrate is then exported offshore. The respective contributions of the coastal upwelling source and the biological sink are of minor importance. As in the southern Saharan Bank, phytoplankton biomass is mostly enhanced by southward advection through the northern boundary exceeding net biological production. Noticeably, this region displays the highest offshore export of phytoplankton. Contributions of southward and vertical transport are weak.

In the Senegalo-Mauritanian region, the nitrate supply is shared between coastal upwelling and northward advection from southern Senegal. Nitrate sinks are almost equally distributed between offshore export, northward advection to Cape Blanc and biological activity. In this region, phytoplankton increases mostly because of net local growth. Phytoplankton transport from the north and toward the south are of minor importance. Phytoplankton is then primarily exported offshore.

Finally, in southern Senegal, nitrate is mostly supplied by advection from the southernmost boundary of our boxes and disappears due to northward advection toward the SenegaloMauritanian region. Contributions of the coastal upwelling source and the biological sink are weaker while the offshore export is even less important. Phytoplankton fluxes are very similar to those found in the Senegalo-Mauritanian region with a main source related to net local growth and a main 


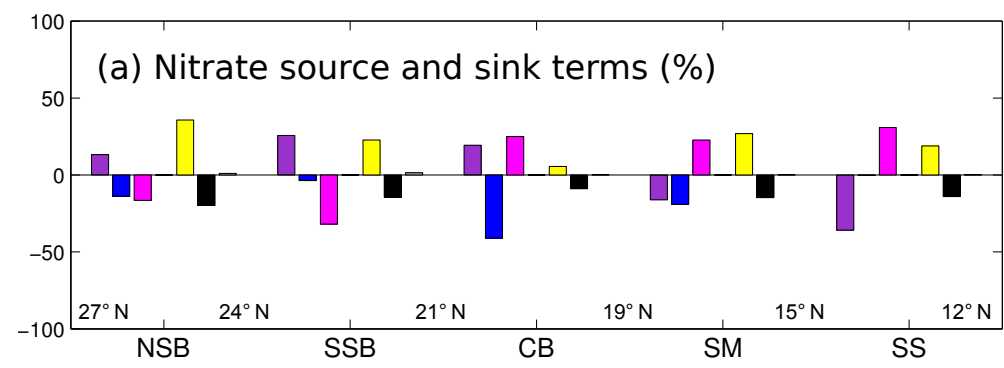

\section{Coastal boxes}
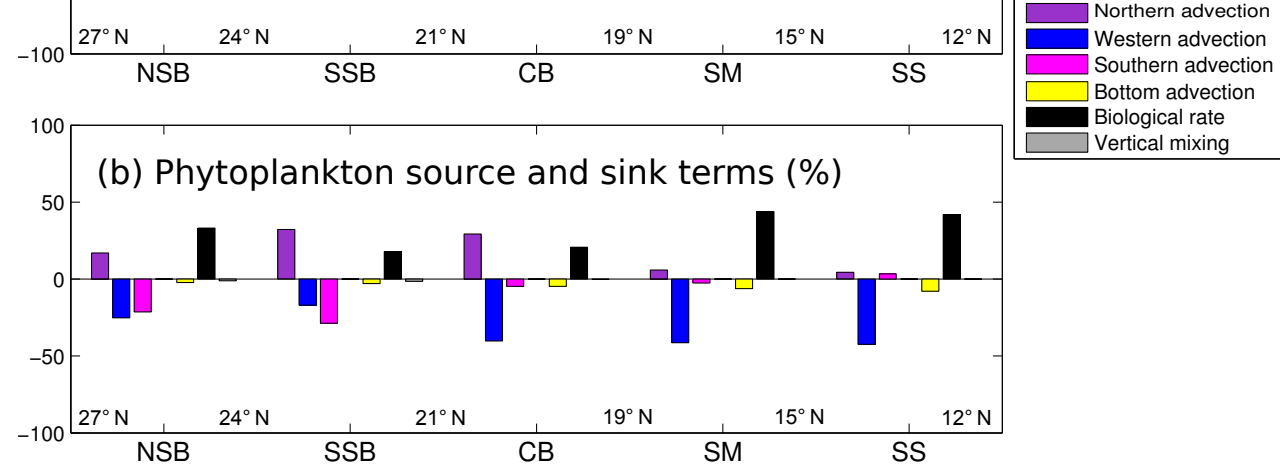

Figure 6. Annual mean contribution of the different source and sink terms of (a) nitrate and (b) phytoplankton biomass in the coastal boxes (\%, positive inward): northern, western and southern horizontal advection, vertical advection and diffusion (vertical mixing) at the bottom and net local biological rate of change. From north to south: northern Saharan Bank (NSB), southern Saharan Bank (SSB), Cape Blanc area (CB), Senegalo-Mauritanian region (SM) and southern Senegal region (SS).

sink through offshore export. Phytoplankton transport from the north and toward the south are of minor importance.

A schematic representing the main fluxes for nitrate and phytoplankton in each box is given in Fig. 7 (each colour corresponds to a box). It shows that coastal upwelling of nitrate, despite being significant in all regions but the Cape Blanc area, is the dominant supplier only in the northern Saharan Bank and the Senegalo-Mauritanian region. In all other regions, nitrate supply is dominated by meridional advection. Indeed, the southern Saharan Bank is mostly fuelled by nitrate advected southward from the northern Saharan Bank while the Cape Blanc area gets nitrate inputs from the southern Saharan Bank and the Senegalo-Mauritanian region. South of this frontal zone in our two southernmost boxes (i.e. the Senegalo-Mauritanian and southern Senegal regions), northward nitrate transport becomes a key player in the nitrate budget. Net local phytoplankton growth is the most important source of phytoplankton in three of our five boxes (i.e. the northern Saharan Bank, SenegaloMauritanian and southern Senegal regions) but this prevalence is mostly marked only in our two southernmost boxes. The three north boxes display close contributions of the phytoplankton supply from northward advection and the net local growth with the latter only dominating in the northernmost box (i.e. the northern Saharan Bank).

\subsection{Spring meridional variability in the offshore region}

\subsubsection{Wind forcing, current velocity and nitrate fluxes}

In the offshore region, the chlorophyll seasonal variability may depend on the export of coastal productivity. Additionally, the wind stress can be responsible for vertical mixing that enhances the exchanges of inorganic and organic matter between the euphotic and aphotic layers. The vertical nutrient supply to the euphotic surface layer and the phytoplankton export below the euphotic layer may also be enhanced by positive or negative Ekman pumping, respectively linked to positive or negative wind stress curl.

Off NW Africa, the offshore extension of coastal chlorophyll has been shown to display a marked seasonal variability with a maximum in spring (Lathuilière et al., 2008). Thus, spring averages from March to May were considered to investigate the factors driving primary productivity in offshore boxes. Mean spring wind forcing (i.e. wind intensity and wind curl) are first presented in Fig. 8a, b. During spring, the wind intensity increases from the northern Saharan Bank to Cape Blanc (where it peaks) and then decreases southward (Fig. 8a). On the other hand, wind stress curl shows a monotonous southward increase (Fig. 8b) from the northern Saharan Bank to southern Senegal with negative values from the northern Saharan Bank to the Cape Blanc region.

During spring, the vertical velocities at the bottom of the offshore boxes display the same meridional structure (Fig. 8c) as the wind curl. As a proxy of offshore export from the coastal band, inward velocities at the eastern boundary are found maximum off the northern Saharan Bank and off 
Nitrate

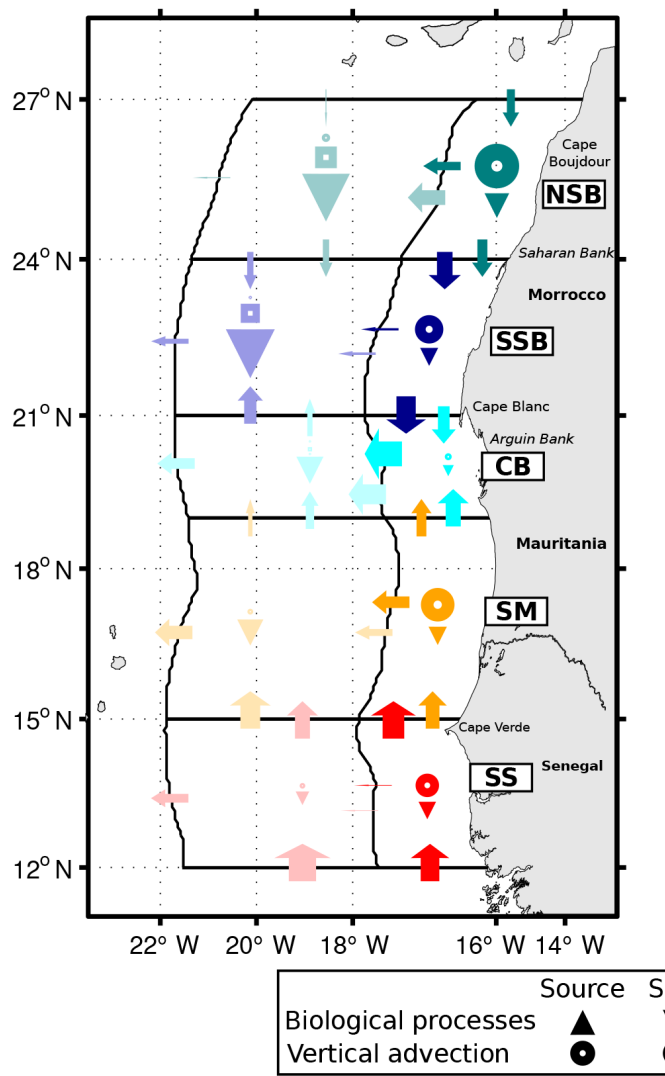

Annual mean

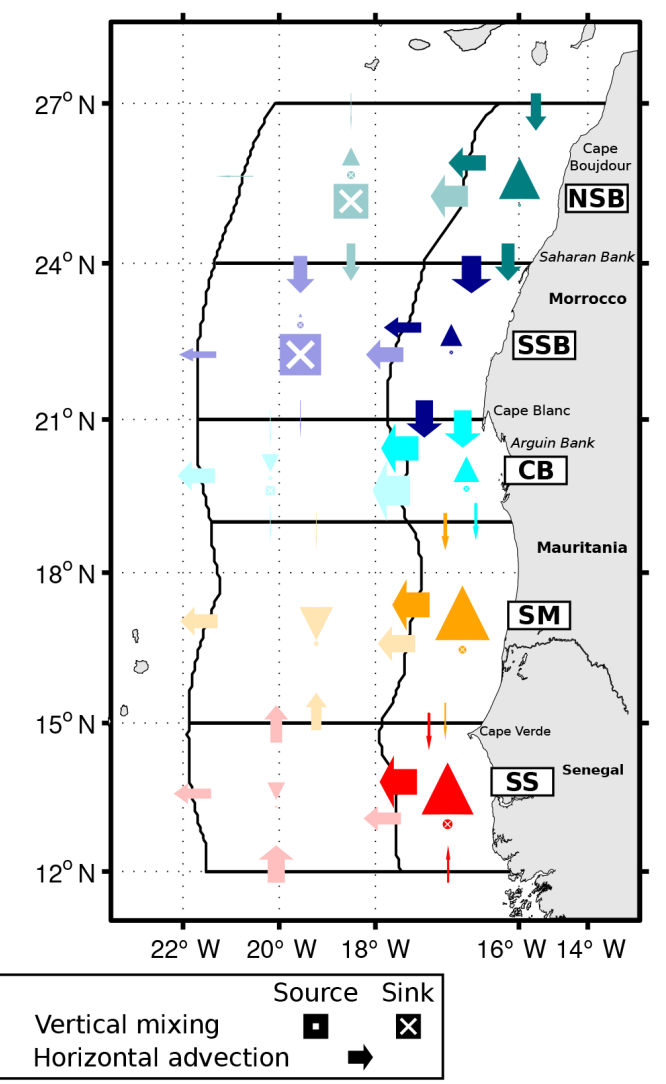

Figure 7. Schematic of the annual mean contribution of the different source and sink terms of nitrate and phytoplankton concentration within each box defined in this study. Each colour corresponds to a box (see legends in Fig. 2 for coastal and Fig. 8 for offshore boxes): northern Saharan Bank (NSB), southern Saharan Bank (SSB), Cape Blanc area (CB), Senegalo-Mauritanian region (SM) and southern Senegal region (SS). Arrows indicate horizontal advection, circles indicate vertical advection, squares indicate vertical mixing and triangles indicate biological processes. Within a circle or square, a white point indicates a source while a white cross indicates a sink; biological processes are a source (sink) if a triangle heads upward (downward). The size of arrows, circles, squares and triangles indicates the magnitude of the contribution of each source and/or sink term. For coastal boxes, the information is equivalent to that given in Fig. 6.

Cape Blanc (Fig. 8g), and minimum off the southern Saharan Bank. It is noteworthy that at the western boundaries, velocities are directed offshore except off the northern Saharan Bank where shoreward intrusions from the subtropical gyre are detected (Fig. 8e). Maximum offshore velocities are found at the latitude of the Cape Blanc region. Southward velocities are found off the southern Saharan Bank and off Cape Blanc (Fig. 8f) while northward velocities are found off southern Senegal (Fig. 8d). Off the Senegalo-Mauritanian region, inward velocities at both north and southern boundaries indicate the presence of a convergence zone in this latitudinal range during spring (Fig. 8d-f).

Mean spring vertical nitrate fluxes (advection and diffusion) at the bottom of the offshore boxes are presented in Fig. 9a, b. A striking result is that vertical advection fluxes are of the same order of magnitude as diffusion fluxes with an opposite meridional variability. On the one hand, vertical ni- trate supply by advection is found in all offshore boxes (but is weak for the northern Saharan Bank) except in the latitudinal band of the southern Saharan Bank region (Fig. 9a). The vertical nitrate supply by advection off the northern and southern Saharan Bank is particularly weak (inward nitrate fluxes despite averaged outward velocities due to episodic inward events) with respect to vertical diffusion. On the other hand, the vertical nitrate supply due to turbulent diffusion shows a clear southward decrease (Fig. 9b). It is actually stronger off the Saharan Bank (north and south) and Cape Blanc than off Mauritania and Senegal.

The patterns of lateral nitrate fluxes during spring (Fig. 9cf) mainly follow current velocities but with significant deviations (Fig. 8d-g). Maximum alongshore fluxes are found south of Cape Blanc and are directed northward (Fig. 9ce). Nitrate inputs from the coastal band (eastern boundary) increase southward compared to cross-shore currents, espe- 


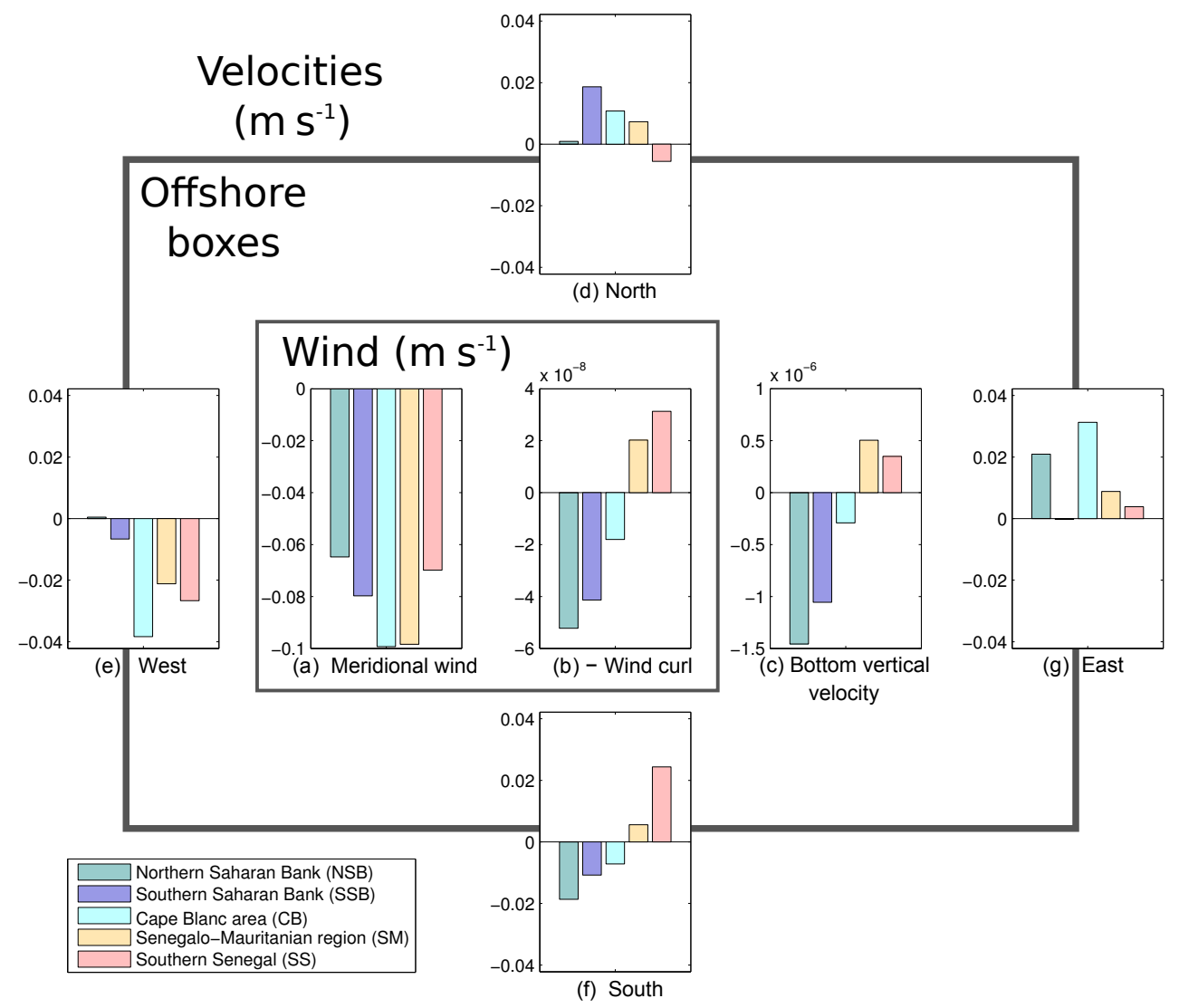

Figure 8. Spring mean (March-May) of (a) wind intensity $\left(\mathrm{m} \mathrm{s}^{-1}\right)$ and (b) wind curl $\left(\mathrm{s}^{-1}\right)$ at the surface of the offshore boxes and (c) upwelling intensity (bottom vertical velocity, in $\mathrm{m} \mathrm{s}^{-1}$ ) within the offshore boxes and lateral velocities at the (d) northern, (e) western, (f) southern and $(\mathbf{g})$ eastern boundaries $\left(\mathrm{ms}^{-1}\right)$. Vertical and lateral velocities are defined as positive inward and upward. Each colour corresponds to a box (see legend).

cially off the Senegalo-Mauritanian region (Fig. 9f), which is attributed to a southward increase of nitrate concentrations in upwelling source waters (Fig. 1). The maximum off Cape Blanc is smoothed compared to current velocities (Fig. 8g), indicating a relative nutrient depletion of coastal waters off Cape Blanc.

\subsubsection{Primary production, phytoplankton biomass and phytoplankton fluxes in spring}

Spring mean PP (new and regenerated production), $f$ ratio and phytoplankton biomass are presented in Fig. 10. According to the meridional pattern of offshore extension of chlorophyll in spring (Lathuilière et al., 2008), offshore PP and phytoplankton biomass are found to be maximum off Cape Blanc and significantly higher in the Senegalo-Mauritanian region than off the Saharan Bank. Both new and regenerated production display the same meridional variability. Nevertheless, regenerated production is generally more intense (except off the northern Saharan Bank) and also more variable in space compared to new production. This corresponds to the meridional variability of ammonium production by both microbial remineralization and zooplankton excretion (Fig. 5b) which respectively contribute to 75 and 30-40\% (15-20\% for both micro- and mesozooplankton, not shown). The meridional variability of PP is then controlled firstly by organic matter inputs from the coastal band which stimulate regenerated production and, less so, by local zooplankton excretion; secondly it is controlled by nutrient inputs from the coastal band responsible for new production.

Mean spring vertical phytoplankton fluxes (advection and diffusion) at the bottom of the offshore boxes are presented in Fig. 11a, b. A striking result is that diffusion fluxes exceed advection fluxes by one order of magnitude. Turbulent diffusion is mostly responsible for vertical export off the Saharan Bank, and to a lesser extent off Cape Blanc (Fig. 11b). Moreover, the offshore vertical export of phytoplankton biomass due to advection exclusively occurs off the Saharan Bank and off Cape Blanc (Fig. 11a). The meridional variability of vertical advection is indeed driven by wind curl (Fig. 8). As a result, the total offshore vertical export is clearly maximum off the Saharan Bank, which is also a sign of maximum dilu- 


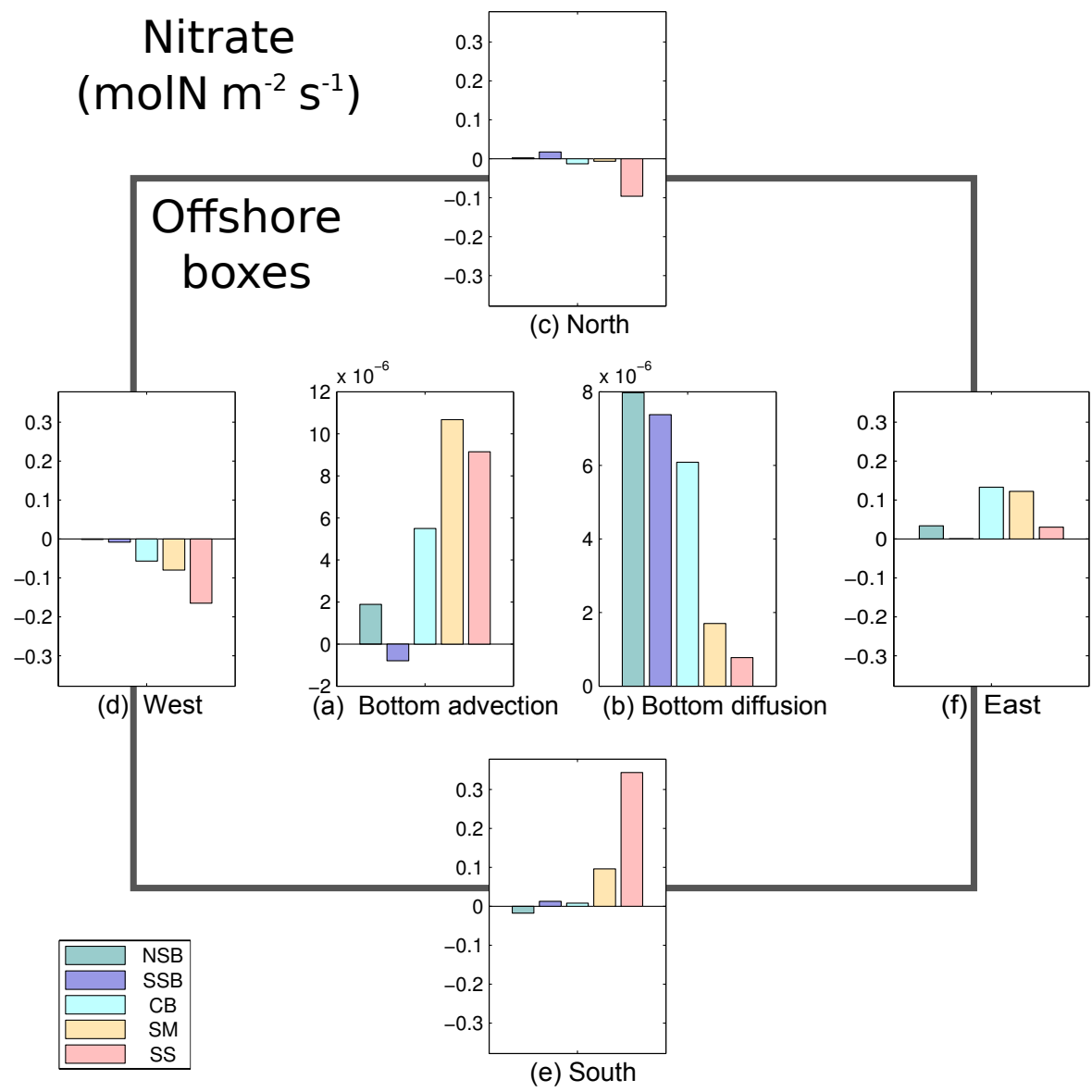

Figure 9. Spring mean (March-May) of vertical nitrate fluxes at the bottom of the offshore boxes by (a) advection and (b) diffusion (vertical mixing) and (c-f) lateral fluxes at the (c) northern, (d) western, (e) southern and (f) eastern boundaries (defined as positive inward and upward) (mol N m${ }^{-2} \mathrm{~s}^{-1}$ ). Each colour corresponds to a box (see legend): northern Saharan Bank (NSB), southern Saharan Bank (SSB), Cape Blanc area (CB), Senegalo-Mauritanian region (SM) and southern Senegal region (SS).

tion of phytoplankton biomass over the water column in this region.

Mean spring phytoplankton horizontal advective fluxes at the boundaries of offshore boxes are presented in Fig. 11c-f. The meridional variability of lateral phytoplankton fluxes is nearly the same as current velocities (Fig. 8d-g). Nevertheless, the westward fluxes through the eastern boundary are more important than expected from lateral velocities from Cape Blanc to Senegal.

\subsubsection{Which processes control the offshore nitrate concentration and phytoplankton biomass?}

Spring mean contribution of each source and sink terms of nitrate concentration and phytoplankton biomass in offshore boxes, i.e. advective and/or diffusive tracer fluxes and net biological rate, are presented in Fig. 12a, b. From northern to southern boxes, the functioning in each box is described. Note that the contribution of horizontal diffusion is negligible compared to vertical diffusion and advection.
In the northern Saharan Bank, the nitrate supply is equally due to coastal inputs and vertical mixing, the contribution of nitrate advection from the north and offshore upwelling remaining insignificant. At the same time, the major sink is found to be the biological activity, clearly exceeding southward advection. Alternatively, in the southern Saharan Bank, the nitrate supply is shared between vertical mixing and northerly advection from the northern Saharan Bank, exceeding southerly advection. Nitrate then mostly disappears due to biological activity. Off Cape Blanc, the nitrate supply is mostly due to coastal inputs, and is then removed by biological activity and offshore export. In the Senegalo-Mauritanian region, the nitrate supply is dominated by coastal inputs, and then northerly advection from southern Senegal and offshore upwelling. In like manner, the nitrate sink is more or less equally distributed between biological activity and westward advection. Finally, in southern Senegal, nitrate is mostly supplied by southerly advection and disappears due to lateral advection (equally distributed between westward and northward advection) more than biological activity. 

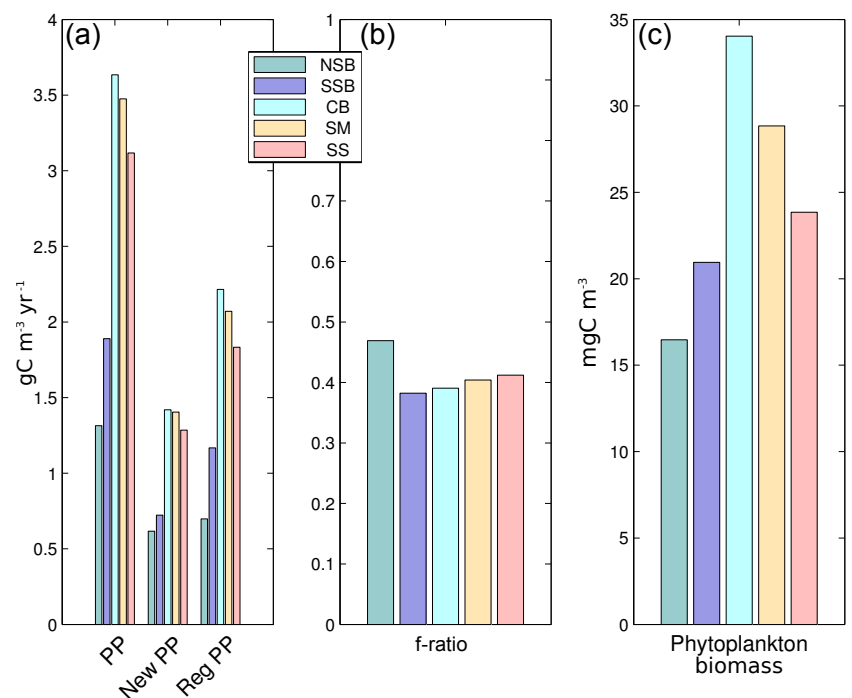

Figure 10. Spring mean (March-May) of (a) primary production (PP, $\left.\mathrm{g} \mathrm{C} \mathrm{m}^{-3} \mathrm{yr}^{-1}\right)$, new production $\left(\mathrm{g} \mathrm{C}^{-3} \mathrm{yr}^{-1}\right)$ and regenerated production $\left(\mathrm{g} \mathrm{C} \mathrm{m}^{-3} \mathrm{yr}^{-1}\right)$, (b) $f$ ratio (new and/or regenerated production) and (c) phytoplankton biomass $\left(\mathrm{mgC} \mathrm{m}^{-3}\right)$ in the offshore boxes. Each colour corresponds to a box (see legend): northern Saharan Bank (NSB), southern Saharan Bank (SSB), Cape Blanc area (CB), Senegalo-Mauritanian region (SM) and southern Senegal region (SS).

The source of phytoplankton biomass off the northern Saharan Bank is equally distributed between net phytoplankton growth and coastal inputs. Phytoplankton biomass is then mostly removed by vertical export through vertical mixing and, less so, by southward transport. Alternatively, in the southern Saharan Bank, phytoplankton biomass is mostly due to lateral advection, equally originating from the north and from the coast, and less so, to net phytoplankton growth. Phytoplankton biomass is still mostly exported vertically through vertical mixing. Off Cape Blanc, the phytoplankton biomass mainly results from coastal inputs and is removed through lateral advection, i.e. offshore and southward, which exceeds the sinks due to vertical mixing and biological activity. Finally, in the Senegalo-Mauritanian and southern Senegal regions, phytoplankton biomass is mostly enhanced by coastal inputs and disappears through biological activity. Southward inputs have also a noticeable contribution off southern Senegal.

To summarize (Fig. 13, each colour corresponds to a box), off the Saharan Bank, nitrate is equally supplied by vertical mixing and lateral advection whether from the coast in the northern Saharan Bank or from the north in the southern Saharan Bank. As a consequence, phytoplankton biomass results from net biological production and lateral advection. Phytoplankton biomass almost exclusively disappears through vertical mixing. Alternatively, south of the Saharan Bank, the nitrate supply is dominated by lateral advection whether from the coast off Cape Blanc, from the coast and the south in the Senegalo-Mauritanian region, or from the south in southern Senegal. In these regions, the phytoplankton biomass is mostly enhanced by zonal advection and disappears through a negative net biological rate. Indeed, the corresponding boxes were defined in the transition zone between eutrophic coastal waters and oligotrophic waters of the subtropical gyre where phytoplankton communities collapse through mortality and grazing. Off Cape Blanc, however, zonal advection dominates due to stronger nutrient and phytoplankton inputs. Thus, the collapse of phytoplankton communities is expected further offshore.

\section{Discussion}

In this study, we investigated the processes driving the meridional variability of phytoplankton biomass and PP in coastal and offshore regions. We will first discuss the sensitivity of coastal upwelling to the wind forcing, which is a key player for the vertical nutrient supply in the coastal region. Then we will focus on the meridional variability of coastal phytoplankton biomass and PP (new and regenerated production) in relation to the transport of matter along the coastal band and to the open ocean. Finally, we will seek to identify the processes driving the meridional variability of the offshore extension of the coastal chlorophyll pattern, which peaks during the spring upwelling season.

\subsection{Sensitivity of coastal upwelling to the wind forcing}

In our simulation, the meridional variability of vertical velocities at $100 \mathrm{~m}$ depth (which roughly corresponds to the euphotic layer) is not correlated to that of upwelling-favourable winds and Ekman pumping on annual average. This result questions the estimation of upwelling-induced nutrient inputs in the euphotic layer based on the wind-driven Ekman transport and the nutrient concentrations in upwelling source waters, a method commonly used in EBUS (Bakun, 1990; Lathuilière et al., 2008; Messié et al., 2009; Messié and Chavez, 2014). However, coastal upwelling depends on many other factors including the large-scale dynamical state of the ocean and the coastal geomorphology (Benazzouz et al., 2014; Mason et al., 2012). As an example, the upwelling limitation by onshore geostrophic flow have been shown to play a key role in driving some coastal upwellings (Marchesiello and Estrade, 2010; Messié and Chavez, 2014). Local and large-scale processes, while not entirely decoupled (e.g. NECC intensity and the seasonal weakening of trade winds are coupled; Mittelstaedt, 1991), act at different timescales and impact in different ways the coastal upwelling. Our simulated spatial and temporal variability of surface circulation is in good agreement with the satellite-tracked drifters (see Sect. 2.2), so the model can be used to infer the factors responsible for the sensitivity of coastal upwelling to the wind forcing. For this latter purpose, we further analyse the sea- 


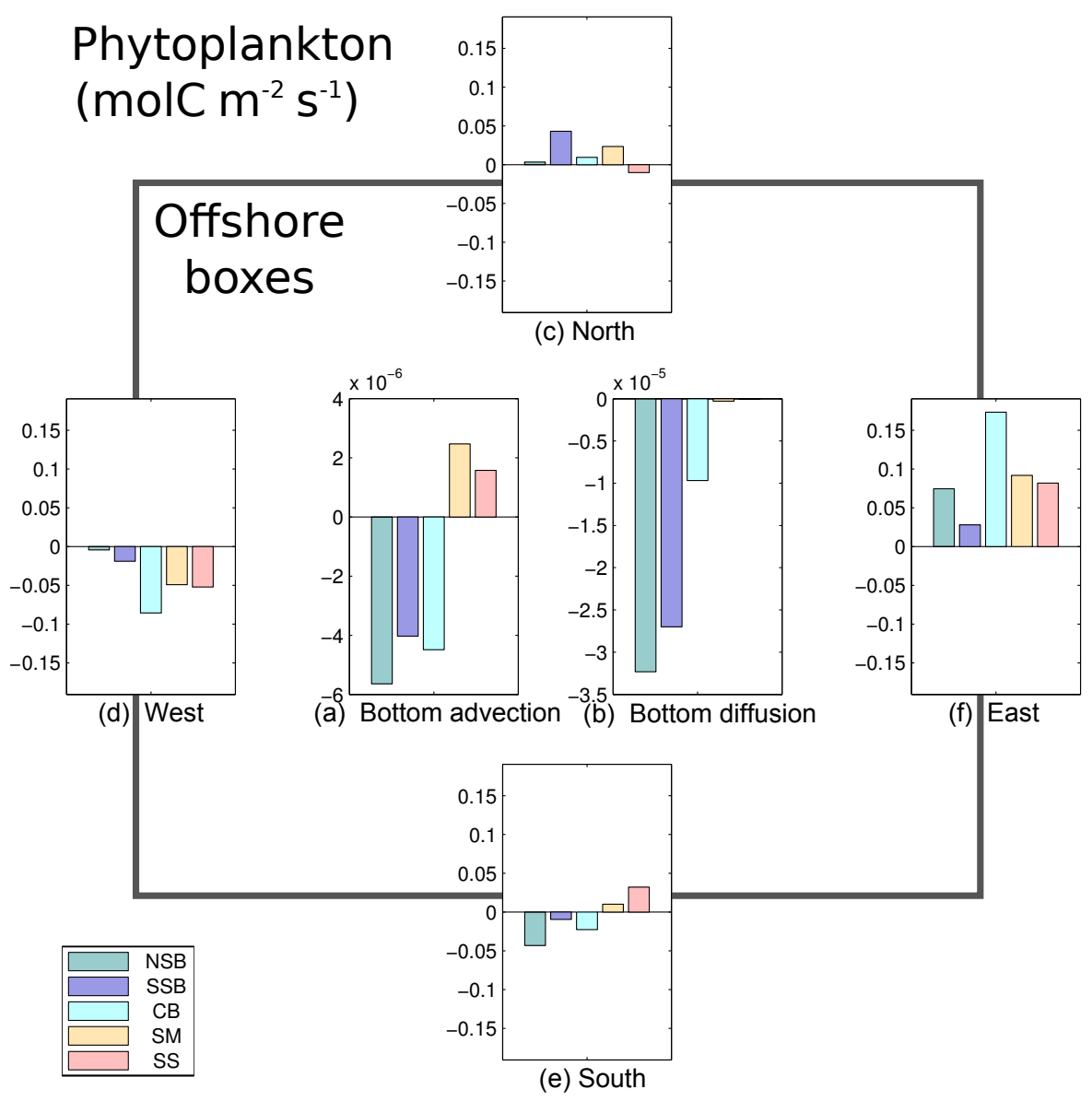

Figure 11. Spring mean (March-May) of vertical phytoplankton fluxes at the bottom of the offshore boxes by (a) advection and (b) diffusion (vertical mixing) and (c-f) lateral fluxes at the (c) northern, (d) western, (e) southern and (f) eastern boundaries (defined as positive inward and upward) (mol $\mathrm{m}^{-2} \mathrm{~s}^{-1}$ ). Each colour corresponds to a box (see legend): northern Saharan Bank (NSB), southern Saharan Bank (SSB), Cape Blanc area (CB), Senegalo-Mauritanian region (SM) and southern Senegal region (SS).

sonal cycles of meridional wind versus vertical and horizontal velocities averaged within and over each edge of the coastal boxes (Fig. 14).

In the northern part of our domain, the presence of the Cape Bojador Filament (Barton et al., 2004; García-Muñoz et al., 2004; Karakaş et al., 2006) leads to a year-round strong offshore export (associated with a strong cross-shore divergence) in the northern Saharan Bank (Fig. 14c). In the southern Saharan Bank and off Cape Blanc, upwelling-favourable wind increases during spring and/or early fall (Fig. 14a). This induces an acceleration of the equatorward jet from the northern Saharan Bank to the Cape Blanc area (Fig. 14d) which tends to create a meridional divergence promoting coastal upwelling over the northern Saharan Bank.

Southward, during the spring/summer and fall/winter transitions, the poleward geostrophic circulation which establishes from southern Senegal to Cape Blanc (Fig. 14d; Lázaro et al., 2005; Mittelstaedt, 1991; Stramma et al., 2005; Wooster et al., 1976) limits the southward extension of the equatorward jet found over the Saharan Bank. It creates a meridional convergence of coastal water masses in the Saharan Bank in the Cape Blanc area (Fig. 14d) which limits significantly the intensity of the coastal upwelling (Fig. 2c). Indeed, a downwelling period is paradoxically found in summer off Cape Blanc when upwelling-favourable wind is maximum (Fig. 14a, b). Downwelling occurs as the cold and dense upwelling water from the Saharan Bank encounters the warm and stratified equatorial water from the NECC (Mittelstaedt, 1991). Noticeably, the response of the Cape Blanc filament (spring and fall peaks of cross-shore velocities) is delayed by 1 month compared to the alongshore jet peaks. This suggests that the local downwelling (driven by meridional convergence) and the inertia of the upwelling jet over the Saharan Bank (as described by Benazzouz et al., 2014) are the primary drivers of the response of the Cape Blanc filament to the wind forcing. In the southernmost part of our domain, the Senegalo-Mauritanian region, the seasonal cycle of the coastal upwelling is likewise partly driven by the equa- 


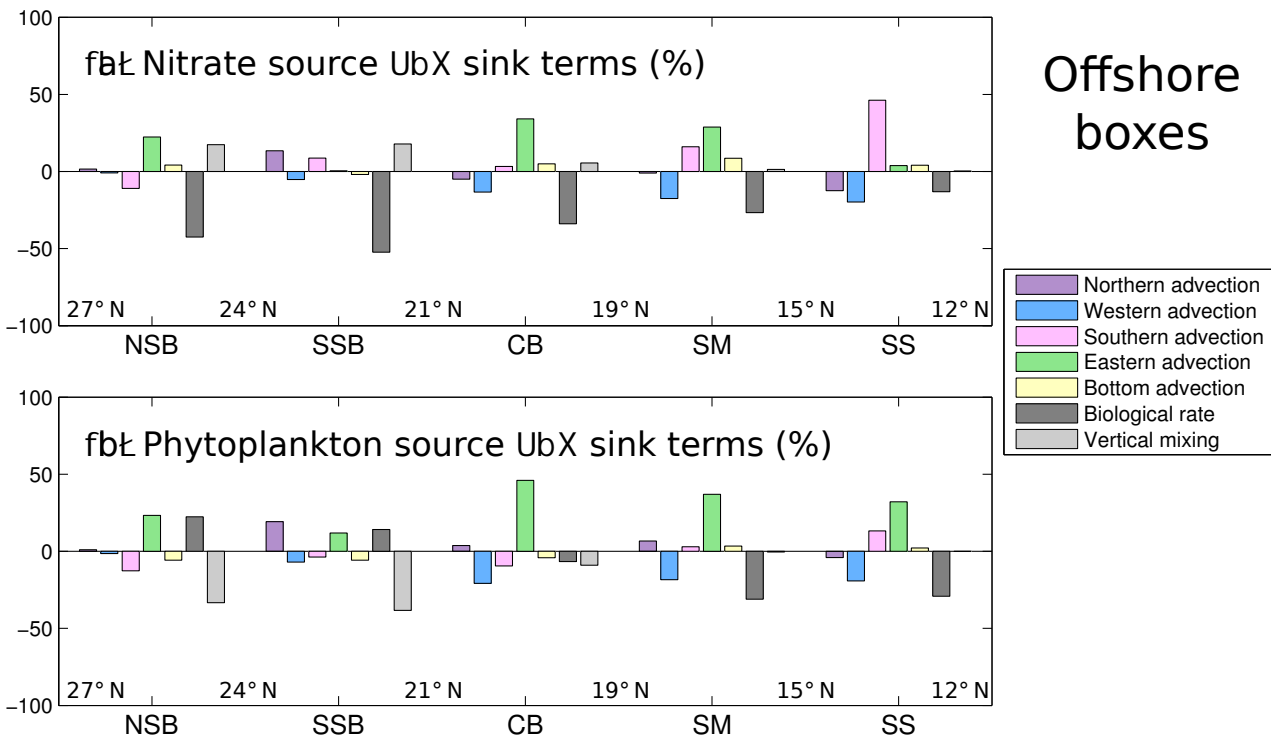

Figure 12. Spring mean (March-May) contribution of the different source and sink terms of (a) nitrate and (b) phytoplankton biomass in the offshore boxes (\%, positive inward): northern, western, southern and eastern horizontal advection, vertical advection and diffusion (vertical mixing) at the bottom, and the net local biological rate of change. From north to south: northern Saharan Bank (NSB), southern Saharan Bank (SSB), Cape Blanc area (CB), Senegalo-Mauritanian region (SM) and southern Senegal region (SS).

torward wind intensity and a downwelling which is detected in late spring while the equatorward wind is weakening (but is not yet minimum).

In the NW African region, coastal topography effects and alongshore geostrophic flow (related to large-scale circulation patterns) may noticeably influence the convergence or divergence of coastal water masses. They would modulate the coastal divergence driven by the Ekman transport, i.e. the response of coastal upwelling to the wind forcing. Our modelling approach stresses processes that are still difficult to study with observations due to their scarcity. Therefore, this work strongly advocates for dedicated observational studies.

\subsection{Meridional variability of coastal phytoplankton biomass, primary production and matter transfers}

Although PP is mainly regulated by new production and the amount of nitrate supply by wind-driven upwelling (Ohde and Siegel, 2010), the meridional variability of PP and phytoplankton biomass is noticeably influenced by regenerated production (fuelled by the uptake of ammonium) on annual average. High regenerated production is a sign that upwelled nitrate is efficiently used (Lachkar and Gruber, 2011; Messié and Chavez, 2014) which has been suggested to result from high residence time in the NW African upwelling system (Lachkar and Gruber, 2011). We show that the meridional variability of regenerated production actually deviates from the variability of new production as a result of (1) the lateral advection of ammonium, particulate detritus and dissolved organic matter that are remineralized, and (2) retention patterns increasing the residence times of water masses.
In the northern Saharan Bank, new production and phytoplankton biomass remain relatively low. Low nitrate concentration in upwelling source waters (North Atlantic Central Water; Arístegui et al., 2009) and short residence time (due to high horizontal advection by the coastal upwelling jet, Fig. 15a) limit the phytoplankton growth. Phytoplankton indeed requires time to complete nutrient uptake (Dugdale et al., 1990; Zimmerman et al., 1987) and low residence times also limit regenerated production leading to minimum PP (Checkley and Barth, 2009; Messié et al., 2009). Upwelled water masses are then exported southward and offshore. Nitrate is mainly exported southward (coastal water masses) while there is relatively more phytoplankton exported offshore. During synoptic events of coastal upwelling, the coastal jet exports nitrate-rich and phytoplankton-poor water masses to the south. Inversely, the relaxation of the coastal jet enhances residence time and promotes the local building of phytoplankton biomass. The combined effect of this local growth and the high filament activity around Cape Bojador (the latter point being documented in Barton et al., 2004; García-Muñoz et al., 2004; Karakaş et al., 2006) results in an offshore transport of phytoplankton-rich and nitrate-depleted water masses.

New production, fuelled by nitrate upwelled in the north Saharan Bank, happens partly further downstream in the southern Saharan Bank where such remote influence accounts for $50 \%$ of new production (Fig. 6). This phenomenon has also been observed downstream of major other upwelling cells, as in the Benguela region for example (Hardman-Mountford et al., 2003). 


\section{Nitrate}

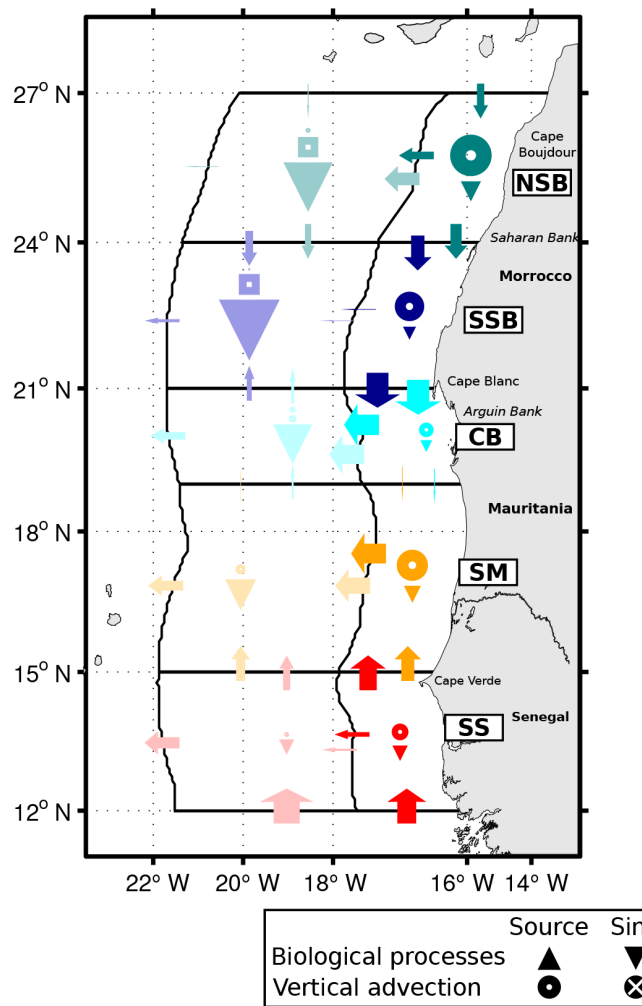

Spring mean
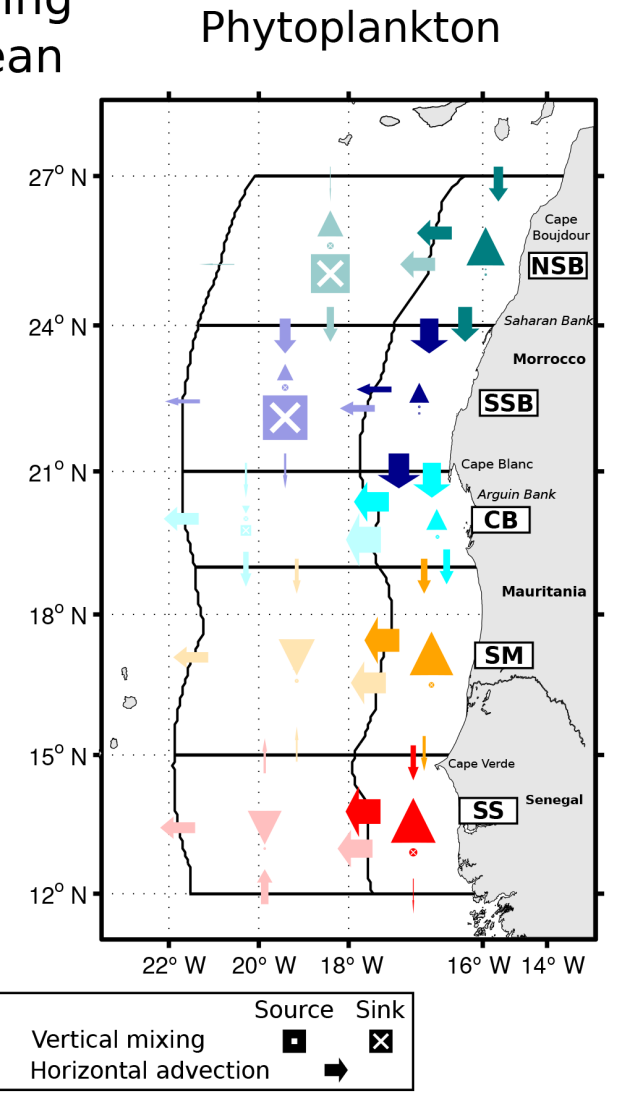

Figure 13. Schematic of the spring mean contribution of the different source and sink terms of nitrate and phytoplankton concentration within each box defined in this study. Each colour corresponds to a box (see legends in Fig. 2 for coastal and Fig. 8 for offshore boxes): northern Saharan Bank (NSB), southern Saharan Bank (SSB), Cape Blanc area (CB), Senegalo-Mauritanian region (SM) and southern Senegal region (SS). Arrows indicate horizontal advection, circles indicate vertical advection, squares indicate vertical mixing and triangles indicate biological processes. Within a circle or square, a white point indicates a source while a white cross indicates a sink; biological processes are a source (sink) if a triangle heads upward (downward). The size of arrows, circles, squares and triangles indicates the magnitude of the contribution of each source and/or sink term. For offshore boxes, the information is equivalent to that given in Fig. 12.

Off Cape Blanc, the meridional convergence of water masses results in subduction events which enhance the vertical extension of the plankton-rich pattern and lead to high levels of phytoplankton biomass when integrated over the $0-100 \mathrm{~m}$ surface layer. The phytoplankton biomass is maintained by maximum levels of regenerated production, actually exceeding new production by more than twofold. In general the regenerated production relies on high residence time favourable to efficient recycling. However, in our results, the water masses' residence time in the southern Saharan Bank and off Cape Blanc is low and can not explain the high level of regenerated production (Fig. 15a). In this region the regenerated production is instead due to the remineralization of organic matter supply and zooplankton excretion (Fig. 5a). Note that the meridional variability of secondary production (grazing rate) follows that of PP (not shown) suggesting a bottom-up control of the phytoplankton biomass rather than a top-down control by zooplankton grazers. Zoo- plankton biomass and excretion activity are then enhanced when the plankton biomass is elevated, which is especially the case in the southern Saharan Bank and off Cape Blanc.

In the Senegalo-Mauritanian region, only moderate regenerated production is found year-round, although residence time is relatively high with respect to the southern Saharan Bank and Cape Blanc areas. This supports the idea that, in the southern Saharan Bank, Cape Blanc and Senegalo-Mauritanian regions, regenerated production is instead driven by the amounts of organic matter supplies through lateral boundaries than by high residence time. In the Senegalo-Mauritanian region, new production is enhanced by vertical nitrate supply during the winter and spring upwelling period (South Atlantic Central Water; Arístegui et al., 2009), and by southerly inputs of equatorial nutrientrich water masses from the Gulf of Guinea in late spring and late fall (Lázaro et al., 2005; Mittelstaedt, 1991). Some authors have also reported the potential impact on primary 
(a) Meridional wind

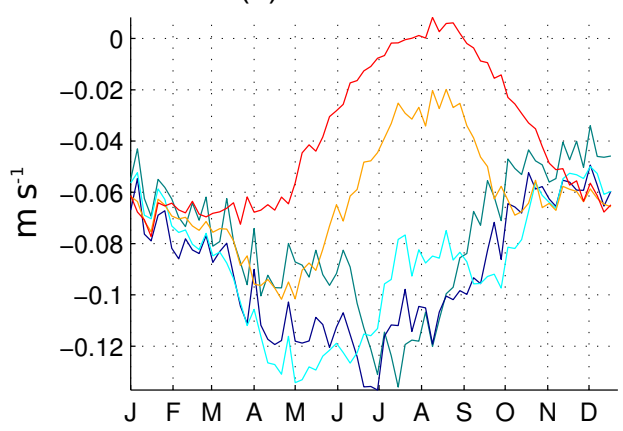

(c) Cross-shore velocity

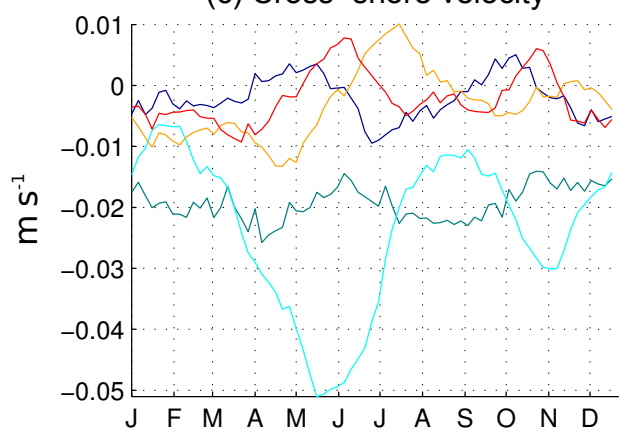

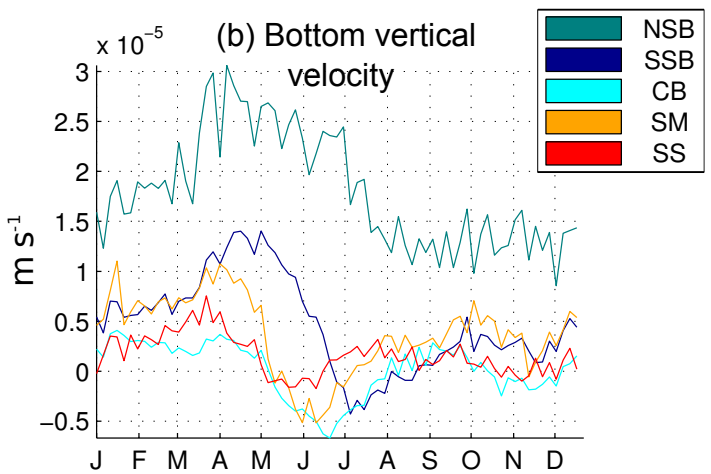

(d) Alongshore velocity

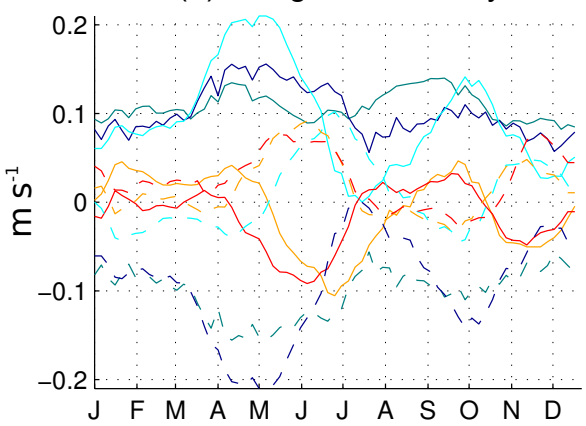

Figure 14. Seasonal climatology of (a) wind intensity (negative is upwelling-favourable, $\mathrm{m} \mathrm{s}^{-1}$ ), (b) bottom vertical velocity ( $\mathrm{ms}^{-1}$ ), (c) zonal velocities $\left(\mathrm{m} \mathrm{s}^{-1}\right)$ and (d) meridional velocities $\left(\mathrm{m} \mathrm{s}^{-1}\right)$ averaged within and over each edge of the coastal boxes (i.e. north, south, west and bottom; defined as positive inward and upward), respectively. In (d), a solid (dashed) line represents a velocity at a northern (southern) edge of a box. Each colour corresponds to a box (see legends in Fig. 2 for coastal and Fig. 8 for offshore boxes): northern Saharan Bank (NSB), southern Saharan Bank (SSB), Cape Blanc area (CB), Senegalo-Mauritanian region (SM) and southern Senegal region (SS).

productivity of horizontal advection of warm, nutrient- and chlorophyll-poor waters by the NECC (Lathuilière et al., 2008) when the trade winds weaken in summer and early fall (Mittelstaedt, 1991; Stramma et al., 2005). Indeed, the weakening of the trade winds and the advection by the NECC are actually coupled but the transition period might enable transient intrusions of nutrient-rich coastal waters from the Gulf of Guinea. Let us also mention that nutrient loads by rivers, which are not accounted for in our model configuration, may significantly sustain marine productivity during the monsoon summer period as high coastal concentrations of nutrients have been recently observed at the end of this rainy season in southern Senegal (E. Machu, personal communication, 2016).

At the coast, the meridional variability of new production follows the pattern of vertical nitrate supply, except off Cape Blanc where maximum new production and phytoplankton biomass are mostly related to lateral nitrate injections. This points to a gap in the first estimates of nitrate supply by coastal upwelling based on the wind-driven Ekman transport and nitrate concentrations in upwelling source waters (Gruber et al., 2011; Messié et al., 2009; Messié and Chavez, 2014), which were used to explore the link between nutrient supply and primary productivity in EBUS. Off NW Africa, this method may actually lead to misleading vertical nitrate supplies in the northern Saharan Bank (underestimation) and off Cape Blanc (overestimation) since the coastal upwelling does not only depend on the wind intensity (see Sect. 4.1). In particular, horizontal convergence and subduction of nutrients in late spring and early summer seem to limit the annual vertical nitrate supply by the upwelling off Cape Blanc in our simulation. Interestingly, satellite-derived diagnostics of low residence time off Cape Blanc (Messié and Chavez, 2014), confirmed by our model results (Fig. 15), also suggest that subduction may play a key role in regulating PP off Cape Blanc. Based on the results of Messié and Chavez (2014), the potential overestimation of vertical nitrate supply identified in this study may also concern other EBUS.

\subsection{Extension of the coastal-rich phytoplankton pattern in spring/summer}

The offshore extension of the coastal surface chlorophyll pattern is highly variable in space and time off NW Africa. As described from SeaWiFS data (Lathuilière et al., 2008), the chlorophyll extension is narrow over the Saharan Bank (less 


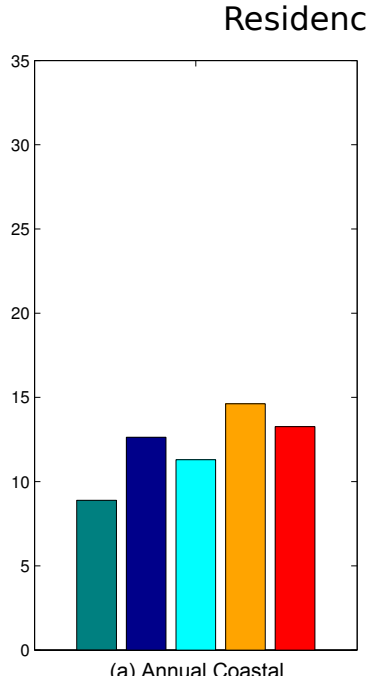

(a) Annual Coastal

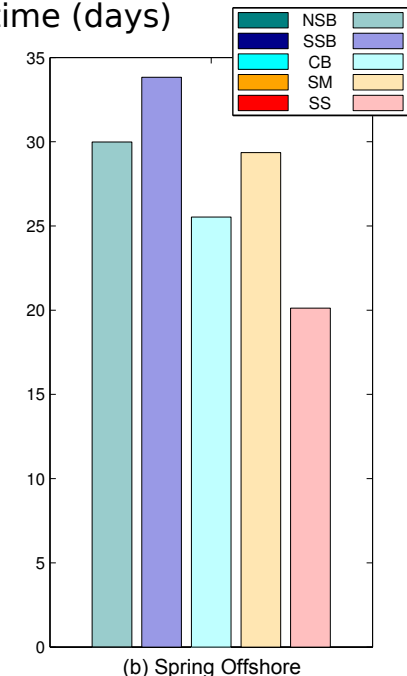

(b) Spring Offshore

Figure 15. (a) Annual mean residence time (in days) of upwelled water masses in the coastal boxes and (b) spring average (MarchMay) residence time (in days) of upwelled water masses in the offshore boxes. Each colour corresponds to a box (see legends in Fig. 2 for coastal and Fig. 8 for offshore boxes): northern Saharan Bank (NSB), southern Saharan Bank (SSB), Cape Blanc area (CB), Senegalo-Mauritanian region (SM) and southern Senegal region (SS).

than $100 \mathrm{~km}$ ), wide off Cape Blanc (approximately $200 \mathrm{~km}$ ) and can reach $400 \mathrm{~km}$ at the end of the spring upwelling season in the Senegalo-Mauritanian region. Focusing on the meridional variations, Lathuilière et al. (2008) investigated the potential impact of several physical and biological processes on this offshore extension: (i) the distance of the upwelling front from the coast, (ii) the wind stress curl, (iii) the impact of mesoscale and submesoscale dynamics on the cross-shelf transport, and (iv) the limitation of phytoplankton growth by nutrients. Our modelling approach was designed to test some of their hypotheses and to better explain the mechanisms driving the offshore extension of surface chlorophyll off NW Africa. For this purpose, we focused on the offshore region in the spring period when the maximum chlorophyll extension is found (Lathuilière et al., 2008). At this season, maximum coastal upwelling is found off the Saharan Bank (Fig. 2c). Following the hypothesis of Lathuilière et al. (2008), this should translate into a maximum of phytoplankton biomass extension at the Saharan Bank latitudes. Instead, maximum extension is found off Cape Blanc and in the Senegalo-Mauritanian region as attested by the meridional variation of phytoplankton biomass in the offshore region (Fig. 10). Note that our conclusions will be also valid on annual average since the drivers of nitrate and phytoplankton biomass in offshore boxes are similar on spring and annual average (see Figs. 7 and 13).

Upward Ekman pumping due to positive wind curl has been reported to contribute significantly to the vertical mass

flux associated with coastal upwelling in a band extending $200 \mathrm{~km}$ from the coast (Castelao and Barth, 2006; Enriquez and Friehe, 1995). Off NW Africa, Ekman pumping has been suggested to contribute to half of the surface chlorophyll variability on an interannual timescale (Pradhan et al., 2006). Our results indicate downward and upward wind-induced Ekman pumping in spring north and south of Cape Blanc, respectively (Figs. 8b, 9a). However, the contribution of vertical advection to the nitrate input in the surface layer is negligible compared to lateral advection and vertical mixing (Fig. 12a). Thus, the offshore extension of the phytoplankton biomass is not primarily driven by the nutrient supply due to Ekman pumping, as already suggested by Lathuilière et al. (2008).

In our results, the vertical mixing contributes significantly to nitrate supply off the Saharan Bank (especially in the southern Saharan Bank, Fig. 12a). This is even more visible in spring when the mixed-layer depth can reach more than $100 \mathrm{~m}$ off the Saharan Bank as a result of winter convection, while remaining generally less than $60 \mathrm{~m}$ in the SenegaloMauritanian region (not shown). This is consistent with the global climatology of the mixed-layer depth from de Boyer Montégut et al. (2004). However, such nitrate supply does not translate into high phytoplankton biomass. In fact, the vertical mixing, as previously suggested by Huntsman and Barber (1977), is also responsible for a significant vertical export of phytoplankton biomass below $100 \mathrm{~m}$ which may limit the phytoplankton biomass off the Saharan Bank. The redistribution of phytoplankton biomass within the mixed layer most likely decreases the surface phytoplankton biomass detected by satellite (dilution effect) which may partly explain the weak offshore extension of surface chlorophyll north of Cape Blanc (Lathuilière et al., 2008).

Overall, our study shows that the lateral advection of nutrients and phytoplankton biomass is mostly directed alongshore (southward) off the Saharan Bank and cross-shore south of Cape Blanc all year round. Thus, inputs of nutrients and phytoplankton biomass from the coast are mainly found south of Cape Blanc (Fig. 9f, 11f). This is consistent with the high regenerated production (Fig. 10) found together with low residence times south of Cape Blanc (Fig. 15b). Nutrient limitation might then play a minor role in the weak offshore extension of chlorophyll north of Cape Blanc questioning the contradictory hypothesis of Lathuilière et al. (2008). In our results, the advection by filaments is found to be a major process enhancing cross-shelf transport off Cape Blanc, in agreement with Kostianoy and Zatsepin (1996). Likewise, high kinetic energy in the Senegalo-Mauritanian region suggests that filaments and mesoscale eddies may enhance crossshelf transport, as shown from satellite data by Lathuilière et al. (2008). In this region, the coastal upwelling jet develops inshore of a large-scale northward circulation, and the resulting current shear may help the development of baroclinic instabilities mostly responsible for eddy generation in upwelling systems (Capet et al., 2008). In contrast, off the 
Saharan Bank, the coastal upwelling jet flows southward together with the Canary Current which may limit the development of such mesoscale activity. The greater offshore extension of the coastal phytoplankton biomass in the SenegaloMauritanian region may then be primarily explained by the lateral advection of nutrients and phytoplankton biomass, as already suggested by Lathuilière et al. (2008). Nevertheless, our model results indicate that the nutrient input is not only from the coastal region. Indeed, we identified a significant impact of transient southern intrusions of nutrient-rich waters in the Senegalo-Mauritanian region originating from the Guinean upwelling due to the presence of the Guinea Dome, a large-scale cyclonic feature centred south of the Cape Verde archipelago (Lázaro et al., 2005; Mittelstaedt, 1991).

\section{Conclusions}

In the present study, a physical-biogeochemical modelling approach seeks to provide the first mechanistic understanding of the drivers of the spatial distribution of primary productivity in the NW African upwelling system. To this aim, a comparative box analysis representing homogeneous subregions in terms of near-surface horizontal circulation was conducted. Our physical-biogeochemical simulation reproduced accurately observed patterns of surface ocean circulation and chlorophyll in our region of interest. We then analysed the distribution of phytoplankton biomass and production with regard to advective and diffusive fluxes of nutrients and phytoplankton at the box boundaries.

Our results suggest that coastal topography effects and alongshore geostrophic flow related to large-scale circulation patterns modulate the coastal divergence driven by the Ekman transport. The effect of wind is amplified off Cape Bojador and dampened off Cape Blanc. Coastal upwelling of nitrate, despite being significant in all regions but the Cape Blanc area, is the dominant supplier only in the northern Saharan Bank and the Senegalo-Mauritanian region. Elsewhere, nitrate supply is dominated by meridional advection. Thus, the meridional variability of new production follows that of vertical nitrate supply, except off Cape Blanc where maximum new production is mostly related to lateral nitrate injections from the northern or southern part of our domain, depending on seasonality. Net local phytoplankton growth is the exclusive driver of phytoplankton biomass only in the Senegalo-Mauritanian region. North of Cape Blanc, the phytoplankton supply from northward advection becomes as important as the net local phytoplankton growth, with the latter only dominating off Cape Bojador. The phytoplankton biomass is also maintained by high levels of regenerated production exceeding new production by more than twofold off Cape Blanc in particular. While the regenerated production relies on high residence time favourable to efficient recycling in the southern Saharan Bank, regenerated production is more impacted by the amounts of organic matter supplies through lateral boundaries than by residence time in the Cape Blanc and Senegalo-Mauritanian regions.

As previously suggested by Lathuilière et al. (2008), the offshore extension of the phytoplankton biomass in spring, more pronounced south of Cape Blanc, is not driven by the nutrient supply due to Ekman pumping. We additionally show that, off the Saharan Bank, the vertical mixing is responsible for a significant vertical export of phytoplankton biomass below $100 \mathrm{~m}$ which is not the case south of Cape Blanc. Besides, the redistribution of phytoplankton biomass within the mixed layer may artificially decrease the surface phytoplankton biomass detected by satellite north of Cape Blanc (dilution effect). Overall, the lateral advection of nutrients and phytoplankton biomass is mostly directed alongshore (southward) off the Saharan Bank and cross-shore south off Cape Blanc. Nutrient limitation due to low nutrient concentrations in upwelling source waters might then only play a minor role in the weak offshore extension of surface chlorophyll north of Cape Blanc. The greater offshore extension of phytoplankton biomass in the SenegaloMauritanian region then effectively results from a lateral advection of coastal nutrients and phytoplankton biomass. Nevertheless, the nutrient input is not only from the coast as transient southern intrusions of nutrient-rich waters from the Guinean upwelling may significantly fertilize the SenegaloMauritanian region.

Future studies should investigate the response in primary productivity to the intra-seasonal and event-scale variability of wind-induced coastal upwelling and nutrient inputs at the box boundaries, and its impact on interannual variability. The year-to-year evolution of fish stocks and migrations may greatly depend on changes in the physical and biogeochemical conditions. This could be tested using our modelling approach by comparing our model inter-annual variability with estimations of fish abundance in the NW African region. Understanding the processes which drive seasonal and interannual variability of this upwelling region also represents a first step towards a robust projection of the effect of climate change on the biogeochemistry of the region and therefore on the fisheries resources.

\section{Data availability}

The source code of the ROMS-PISCES platform is available at https://www.croco-ocean.org/download/roms_ agrifproject. Data used in this study can be obtained directly by contacting the authors.

Acknowledgements. We firstly want to thank I. Ruvalcaba Baroni and two anonymous referees for greatly improving the paper. We are deeply indebted to Pierrick Penven, Xavier Capet and Elodie Gutknecht for methodological discussions. We also wish to thank Tristan Le Toullec and computer engineers from the Institut Universitaire Européen de la Mer (IUEM, Brest, France), 
particularly Emmanuel Taboré, for their technical support. The present work was supported by the Franco-Moroccan EPURE project (Eléments trace métalliques, Pollution, Upwelling et Ressources - http://anr-epure.net) under the call CEP\&S of the French National Research Agency (ANR), the AWA project (no. 01DG12073E, Ecosystem Approach to the management of fisheries and the marine environment in West African waters - http://www.awa-project.org), the FP7 PREFACE project (no. 603521, Enhancing prediction of Tropical Atlantic climate and its impacts - http://preface.b.uib.no) and the LabexMER (no. ANR10-LABX-19-01, http://www.labexmer.eu). Open boundary conditions for our regional simulation were provided by the FP7 EURO-BASIN project (no. 264933). Numerical simulations were performed using HPC resources from CAPARMOR (CAlcul PARallèle Mutualisé pour l'Océanographie et la Recherche), a cluster hosted at Ifremer (Brest, France). Additional support during the writing phase was provided by the Instituto Milenio de Oceanografia (IMO-Chile), funded by the Iniciativa Cientifica Milenio (ICM-Chile).

Edited by: C. P. Slomp

Reviewed by: I. Ruvalcaba Baroni and two anonymous referees.

\section{References}

Aiken, J., Pradhan, Y., Barlow, R., Lavender, S., Poulton, A., Holligan, P., and Hardman-Mountford, N.: Phytoplankton pigments and functional types in the Atlantic Ocean: A decadal assessment, 1995-2005, Deep-Sea Res. Pt. II, 56, 899-917, doi:10.1016/j.dsr2.2008.09.017, 2009.

Albert, A., Echevin, V., Lévy, M., and Aumont, O.: Impact of nearshore wind stress curl on coastal circulation and primary productivity in the Peru upwelling system, J. Geophys. Res., 115, doi:10.1029/2010JC006569, 2010.

Allen, J. S.: Upwelling and Coastal Jets in a Continuously Stratified Ocean, J. Phys. Oceanogr., 3, 245-257, doi:10.1175/15200485(1973)003<0245:UACJIA>2.0.CO;2, 1973.

Arístegui, J., Barton, E. D., Tett, P., Montero, M. F., GarcíaMuñoz, M., Basterretxea, G., Cussatlegras, A.-S., Ojeda, A., and de Armas, D.: Variability in plankton community structure, metabolism, and vertical carbon fluxes along an upwelling filament (Cape Juby, NW Africa), Prog. Oceanogr., 62, 95-113, doi:10.1016/j.pocean.2004.07.004, 2004.

Arístegui, J., Barton, E. D., Álvarez-Salgado, X. A., Santos, A. M. P., Figueiras, F. G., Kifani, S., Hernández-León, S., Mason, E., Machú, E., and Demarcq, H.: Sub-regional ecosystem variability in the Canary Current upwelling, Prog. Oceanogr., 83, 33-48, doi:10.1016/j.pocean.2009.07.031, 2009.

Auger, P. A., Machu, E., Gorgues, T., Grima, N., and Waeles, M.: Comparative study of potential transfer of natural and anthropogenic cadmium to plankton communities in the NorthWest African upwelling, Sci. Total Environ., 505, 870-888, doi:10.1016/j.scitotenv.2014.10.045, 2015.

Aumont, O. and Bopp, L.: Globalizing results from ocean in situ iron fertilization studies, Glob. Biogeochem. Cy., 20, GB2017, doi:10.1029/2005GB002591, 2006.

Aumont, O., Maier-Reimer, E., Blain, S., and Monfray, P.: An ecosystem model of the global ocean including $\mathrm{Fe}, \mathrm{Si}, \mathrm{P}$ colimita- tions, Glob. Biogeochem. Cy., 17, doi:10.1029/2001GB001745, 2003.

Aumont, O., Bopp, L., and Schulz, M.: What does temporal variability in aeolian dust deposition contribute to sea-surface iron and chlorophyll distributions?, Geophys. Res. Lett., 35, L07607, doi:10.1029/2007GL031131, 2008.

Bakun, A.: Global Climate Change and Intensification of Coastal Ocean Upwelling, Science, 247, 198-201, doi:10.2307/2873492, 1990.

Barton, E. D., Arıstegui, J., Tett, P., Cantón, M., Garcı-Braun, J., Hernández-León, S., Nykjaer, L., Almeida, C., Almunia, J., and Ballesteros, S.: The transition zone of the Canary Current upwelling region, Prog. Oceanogr., 41, 455-504, doi:10.1016/S0079-6611(98)00023-8, 1998.

Barton, E. D., Arístegui, J., Tett, P., and Navarro-Pérez, E.: Variability in the Canary Islands area of filament-eddy exchanges, Prog. Oceanogr., 62, 71-94, doi:10.1016/j.pocean.2004.07.003, 2004.

Benazzouz, A., Pelegrí, J. L., Demarcq, H., Machín, F., Mason, E., Orbi, A., Peña-Izquierdo, J., and Soumia, M.: On the temporal memory of coastal upwelling off NW Africa, J. Geophys. Res.Oceans, 119, 6356-6380, doi:10.1002/2013JC009559, 2014.

Benítez-Barrios, V. M., Pelegrí, J. L., Hernández-Guerra, A., Lwiza, K. M. M., Gomis, D., Vélez-Belchí, P., and HernándezLeón, S.: Three-dimensional circulation in the NW Africa coastal transition zone, Prog. Oceanogr., 91, 516-533, doi:10.1016/j.pocean.2011.07.022, 2011.

Capet, X., Colas, F., McWilliams, J. C., Penven, P., and Marchesiello, P.: Eddies in eastern boundary subtropical upwelling systems, edited by: Hecht, M. W. and Hasumi, H., Geophys. Monogr. Ser., 177, 131-147, doi:10.1029/177GM10, 2008.

Carr, M. E.: Estimation of potential productivity in Eastern Boundary Currents using remote sensing, Deep-Sea Res. Pt. II, 49, 59 80, doi:10.1016/S0967-0645(01)00094-7, 2001.

Carr, M. E. and Kearns, E. J.: Production regimes in four Eastern Boundary Current systems, Deep-Sea Res. Pt. II, 50, 3199-3221, doi:10.1016/j.dsr2.2003.07.015, 2003.

Castelao, R. M. and Barth, J. A.: Upwelling around Cabo Frio, Brazil: The importance of wind stress curl, Geophys. Res. Lett., 33, doi:10.1029/2005GL025182, 2006.

Checkley, D. M. and Barth, J. A.: Patterns and processes in the California Current System, Prog. Oceanogr., 83, 49-64, doi:10.1016/j.pocean.2009.07.028, 2009.

Debreu, L., Marchesiello, P., Penven, P., and Cambon, G.: Two-way nesting in split-explicit ocean models: Algorithms, implementation and validation, Ocean Model., 49/50, 1-21, doi:10.1016/j.ocemod.2012.03.003, 2012.

de Boyer Montégut, C., Madec, G., Fischer, A. S., Lazar, A., and Iudicone, D.: Mixed layer depth over the global ocean: An examination of profile data and a profile-based climatology, J. Geophys. Res., 109, doi:10.1029/2004JC002378, 2004.

Dugdale, R. C., Wilkerson, F. P., and Morel, A.: Realization of new production in coastal upwelling areas: A means to compare relative performance, Limnol. Oceanogr., 35, 822-829, doi:10.4319/lo.1990.35.4.0822, 1990.

Echevin, V., Aumont, O., Ledesma, J., and Flores, G.: The seasonal cycle of surface chlorophyll in the Peruvian upwelling system: A modelling study, Prog. Oceanogr., 79, 167-176, doi:10.1016/j.pocean.2008.10.026, 2008. 
Enriquez, A. G. and Friehe, C. A.: Effects of Wind Stress and Wind Stress Curl Variability on Coastal Upwelling, J. Phys. Oceanogr., 25, 1651-1671, doi:10.1175/15200485(1995)025<1651:EOWSAW>2.0.CO;2, 1995.

Garcia, H. E., Locarnini, R. A., Boyer, T. P., Antonov, J. I., Baranova, O. K., Zweng, M. M., Reagan, J. R., and Johnson, D. R.: World Ocean Atlas 2013, Volume 4: Dissolved Inorganic Nutrients (phosphate, nitrate, silicate), edited by: Levitus, S., A. Mishonov Technical Ed.; NOAA Atlas NESDIS 76, 25 pp., 2014.

García-Muñoz, M., Arístegui, J., Montero, M. F., and Barton, E. D.: Distribution and transport of organic matter along a filament-eddy system in the Canaries - NW Africa coastal transition zone region, Prog. Oceanogr., 62, 115-129, doi:10.1016/j.pocean.2004.07.005, 2004.

García-Muñoz, M., Arístegui, J., Pelegrí, J. L., Antoranz, A., Ojeda, A., and Torres, M.: Exchange of carbon by an upwelling filament off Cape Ghir (NW Africa), J. Mar. Syst., 54, 83-95, doi:10.1016/j.jmarsys.2004.07.005, 2005.

Gibb, S. W., Barlow, R. G., Cummings, D. G., Rees, N. W., Trees, C. C., Holligan, P., and Suggett, D.: Surface phytoplankton pigment distributions in the Atlantic Ocean: an assessment of basin scale variability between $50^{\circ} \mathrm{N}$ and $50^{\circ} \mathrm{S}$, Prog. Oceanogr., 45, 339368, doi:10.1016/S0079-6611(00)00007-0, 2000.

Gorgues, T., Menkes, C., Aumont, O., Vialard, J., Dandonneau, Y., and Bopp, L.: Biogeochemical impact of tropical instability waves in the equatorial Pacific, Geophys. Res. Lett., 32, doi:10.1029/2005GL024110, 2005.

Gorgues, T., Aumont, O., and Rodgers, K. B.: A mechanistic account of increasing seasonal variations in the rate of ocean uptake of anthropogenic carbon, Biogeosciences, 7, 2581-2589, doi:10.5194/bg-7-2581-2010, 2010.

Gregg, W. W. and Casey, N. W.: Global and regional evaluation of the SeaWiFS chlorophyll data set, Remote Sens. Environ., 93, 463-479, doi:10.1016/j.rse.2003.12.012, 2004.

Gregg, W. W., Conkright, M. E., Ginoux, P., O'Reilly, J. E., and Casey, N. W.: Ocean primary production and climate: Global decadal changes, Geophys. Res. Lett., 30, doi:10.1029/2003GL016889, 2003.

Gruber, N., Lachkar, Z., Frenzel, H., Marchesiello, P., Münnich, M., McWilliams, J. C., Nagai, T., and Plattner, G.-K.: Eddy-induced reduction of biological production in eastern boundary upwelling systems, Nat. Geosci., 4, 787-792, doi:10.1038/ngeo1273, 2011.

Gutiérrez-Rodríguez, A., Latasa, M., Agustí, S., and Duarte, C. M.: Distribution and contribution of major phytoplankton groups to carbon cycling across contrasting conditions of the subtropical northeast Atlantic Ocean, Deep-Sea Res., 58, 1115-1129, doi:10.1016/j.dsr.2011.08.003, 2011.

Hardman-Mountford, N. J., Richardson, A. J., Agenbag, J. J., Hagen, E., Nykjaer, L., Shillington, F. A., and Villacastin, C.: Ocean climate of the South East Atlantic observed from satellite data and wind models, Prog. Oceanogr., 59, 181-221, doi:10.1016/j.pocean.2003.10.001, 2003.

Helmke, P., Romero, O., and Fischer, G.: Northwest African upwelling and its effect on offshore organic carbon export to the deep sea, Glob. Biogeochem. Cy., 19, doi:10.1029/2004GB002265, 2005.

Huntsman, S. A. and Barber, R. T.: Primary production off northwest Africa: the relationship to wind and nutrient conditions,
Deep-Sea Res., 24, 25-33, doi:10.1016/0146-6291(77)90538-0, 1977.

José, Y. S., Aumont, O., Machu, E., Penven, P., Moloney, C. L., and Maury, O.: Influence of mesoscale eddies on biological production in the Mozambique Channel: Several contrasted examples from a coupled ocean-biogeochemistry model, Deep-Sea Res. Pt. II, 100, 79-93, doi:10.1016/j.dsr2.2013.10.018, 2014.

Karakaş, G., Nowald, N., Blaas, M., Marchesiello, P., Frickenhaus, S., and Schlitzer, R.: High-resolution modeling of sediment erosion and particle transport across the northwest African shelf, J. Geophys. Res., 111,Deep Sea doi:10.1029/2005JC003296, 2006.

Kostianoy, A. G. and Zatsepin, A. G.: The West African coastal upwelling filaments and cross-frontal water exchange conditioned by them, J. Mar. Syst., 7, 349-359, doi:10.1016/09247963(95)00029-1, 1996.

Lachkar, Z. and Gruber, N.: What controls biological production in coastal upwelling systems? Insights from a comparative modeling study, Biogeosciences, 8, 2961-2976, doi:10.5194/bg-82961-2011, 2011.

Lathuilière, C., Echevin, V., and Lévy, M.: Seasonal and intraseasonal surface chlorophyll-a variability along the northwest African coast, J. Geophys. Res., 113, doi:10.1029/2007JC004433, 2008.

Lázaro, C., Joana Fernandes, M., Santos, A. M. P., and Oliveira, P.: Seasonal and interannual variability of surface circulation in the Cape Verde region from 8 years of merged $T / P$ and ERS-2 altimeter data, Remote Sens. Environ., 98, 45-62, doi:10.1016/j.rse.2005.06.005, 2005.

Lumpkin, R. and Johnson, G. C.: Global ocean surface velocities from drifters: Mean, variance, El Niño-Southern Oscillation response, and seasonal cycle: Global Ocean Surface Velocities, J. Geophys. Res.-Oceans, 118, 2992-3006, doi:10.1002/jgrc.20210, 2013.

Machu, E., Ettahiri, O., Kifani, S., Benazzouz, A., Makaoui, A., and Demarcq, H.: Environmental control of the recruitment of sardines (Sardina pilchardus) over the western Saharan shelf between 1995 and 2002: a coupled physical/biogeochemical modelling experiment, Fish. Oceanogr., 18, 287-300, doi:10.1111/j.1365-2419.2009.00511.x, 2009.

Marañon, E., Holligan, P. M., Varela, M., Mouriño, B., and Bale, A. J.: Basin-scale variability of phytoplankton biomass, production and growth in the Atlantic Ocean, Deep-Sea Res. Part Oceanogr. Res. Pap., 47, 825-857, doi:10.1016/S0967-0637(99)00087-4, 2000.

Marchesiello, P. and Estrade, P.: Eddy activity and mixing in upwelling systems: a comparative study of Northwest Africa and California regions, Int. J. Earth Sci., 98, 299-308, doi:10.1007/s00531-007-0235-6, 2009.

Marchesiello, P. and Estrade, P.: Upwelling limitation by onshore geostrophic flow, J. Mar. Res., 68, 37-62, doi:10.1357/002224010793079004, 2010.

Mason, E., Colas, F., and Pelegrí, J. L.: A Lagrangian study tracing water parcel origins in the Canary Upwelling System, Sci. Mar., 76, 79-94, doi:10.3989/scimar.03608.18D, 2012.

Messié, M. and Chavez, F. P.: Seasonal regulation of primary production in eastern boundary upwelling systems, Prog. Oceanogr., 134, 1-18, doi:10.1016/j.pocean.2014.10.011, 2014.

Messié, M., Ledesma, M., Kolber, D. D., Michisaki, R. P., Foley, D. G., and Chavez, F. P.: Potential new production estimates in 
four eastern boundary upwelling ecosystems, Prog. Oceanogr., 8 , 151-158, doi:10.1016/j.pocean.2009.07.018, 2009.

Mittelstaedt, E.: The upwelling area off Northwest Africa - a description of phenomena related to coastal upwelling, Prog. Oceanogr., 12, 307-331, doi:10.1016/0079-6611(83)90012-5, 1983.

Mittelstaedt, E.: The ocean boundary along the northwest African coast: Circulation and oceanographic properties at the sea surface, Prog. Oceanogr., 26, 307-355, doi:10.1016/00796611(91)90011-A, 1991.

Moulin, C., Gordon, H. R., Chomko, R. M., Banzon, V. F., and Evans, R. H.: Atmospheric correction of ocean color imagery through thick layers of Saharan dust, Geophys. Res. Lett., 28, 5-8, doi:10.1029/2000GL011803, 2001.

Muller-Karger, F. E., Varela, R., Thunell, R., Luerssen, R., Hu, C., and Walsh, J. J.: The importance of continental margins in the global carbon cycle, Geophys. Res. Lett., 32, doi:10.1029/2004GL021346, 2005.

Ohde, T. and Siegel, H.: Biological response to coastal upwelling and dust deposition in the area off Northwest Africa, Cont. Shelf Res., 30, 1108-1119, doi:10.1016/j.csr.2010.02.016, 2010.

Pradhan, Y., Lavender, S. J., Hardman-Mountford, N. J., and Aiken, J.: Seasonal and inter-annual variability of chlorophyll-a concentration in the Mauritanian upwelling: Observation of an anomalous event during 1998-1999, Deep-Sea Res. Pt. II, 53, 15481559, doi:10.1016/j.dsr2.2006.05.016, 2006.

Saha, S., Moorthi, S., Pan, H.-L., Wu, X., Wang, J., Nadiga, S., Tripp, P., Kistler, R., Woollen, J., and Behringer, D.: The NCEP climate forecast system reanalysis., Bull. Am. Meteorol. Soc., 91, 1015, doi:10.1175/2010BAMS3001.1, 2010.
Shchepetkin, A. F. and McWilliams, J. C.: The regional oceanic modeling system (ROMS): a split-explicit, free-surface, topography-following-coordinate oceanic model, Ocean Model., 9, 347-404, doi:10.1016/j.ocemod.2004.08.002, 2005.

Stramma, L., Hüttl, S., and Schafstall, J.: Water masses and currents in the upper tropical northeast Atlantic off northwest Africa, J. Geophys. Res., 110, doi:10.1029/2005JC002939, 2005.

Sunda, W. G. and Huntsman, S. A.: Interrelated influence of iron, light and cell size on marine phytoplankton growth, Nature, 390, 389-392, doi:10.1038/37093, 1997.

Thomas, A. C., Carr, M. E., and Strub, P. T.: Chlorophyll variability in eastern boundary currents, Geophys. Res. Lett., 28, 34213424, doi:10.1029/2001GL013368, 2001.

Verstraete, J. M.: Contre-courants équatoriaux et variations saisonnières $\mathrm{du}$ contenu thermique et du niveau moyen dans l'Atlantique tropical Est, Oceanol. Acta, 8, 249-261, 1985.

Wooster, W. S., Bakun, A. M. D. R., and McLain, D. R.: Seasonal upwelling cycle along eastern boundary of North-Atlantic, J. Mar. Res., 34, 131-141, 1976.

Zimmerman, R. C., Kremer, J. N., and Dugdale, R. C.: Acceleration of nutrient uptake by phytoplankton in a coastal upwelling ecosystem: A modeling analysis, Limnol. Oceanogr., 32, 359367, doi:10.4319/lo.1987.32.2.0359, 1987. 